\title{
Management of Kidney Failure in Patients with Diabetes Mellitus: What Are the Best Options?
}

\author{
Juan M. Buades ${ }^{1,2, *,+} \oplus$, Lourdes Craver ${ }^{3, \dagger}{ }^{+}$Maria Dolores Del Pino ${ }^{4, \dagger}$, Mario Prieto-Velasco ${ }^{5,+}$, \\ Juan C. Ruiz ${ }^{6,7,+} \oplus$, Mercedes Salgueira ${ }^{8,9,10,+}$, Patricia de Sequera ${ }^{11,12,+}$ and Nicanor Vega ${ }^{13,+}$
}

1 Department of Nephrology, Hospital Universitario Son Llàtzer, Balearic Islands, 07198 Palma de Mallorca, Spain

2 Health Research Institute of the Balearic Islands (IdISBa), 07120 Palma de Mallorca, Spain

3 Department of Nephrology, Hospital Universitario Arnau de Vilanova, 25198 Lleida, Spain; lscraver.lleida.ics@gencat.cat

4 Department of Nephrology, Complejo Hospitalario Torrecárdenas de Almería, 04009 Almería, Spain; mdpinoypino@gmail.com

5 Department of Nephrology, Complejo Asistencial Universitario de Leon, 24001 León, Spain; mprietov@gmail.com

6 Department of Nephrology, Valdecilla Hospital, University of Cantabria, 39008 Santander, Spain; juancarlos.ruiz@scsalud.es

7 Valdecilla Biomedical Research Institute (IDIVAL), Cardenal Herrera Oria S/N, 39011 Santander, Spain

8 Department of Nephrology, Hospital Universitario Virgen Macarena, 41009 Seville, Spain; salgueiramer@gmail.com

9 Biomedical Engineering Group, Medicine Department, University of Seville, 41092 Seville, Spain

check for

updates

Citation: Buades, J.M.; Craver, L.; Del Pino, M.D.; Prieto-Velasco, M.;

Ruiz, J.C.; Salgueira, M.;

de Sequera, P.; Vega, N. Management

of Kidney Failure in Patients with

Diabetes Mellitus: What Are the Best

Options? J. Clin. Med. 2021, 10, 2943.

https://doi.org/10.3390/jcm10132943

Academic Editor:

José María Mora-Gutierrez

Received: 23 May 2021

Accepted: 25 June 2021

Published: 30 June 2021

Publisher's Note: MDPI stays neutral with regard to jurisdictional claims in published maps and institutional affiliations.

Copyright: (c) 2021 by the authors. Licensee MDPI, Basel, Switzerland. This article is an open access article distributed under the terms and conditions of the Creative Commons Attribution (CC BY) license (https:/ / creativecommons.org/licenses/by/ $4.0 /)$.
10 Center for Biomedical Research Network in Bioengineering Biomaterials and Nanomedicina (CIBER-BBN), 28029 Madrid, Spain

11 Department of Nephrology, Hospital Universitario Infanta Leonor, 28031 Madrid, Spain; psequerao@senefro.org

12 Medicine Department, Universidad Complutense de Madrid, 28031 Madrid, Spain

13 Department of Nephrology, Hospital Universitario de Gran Canaria Dr. Negrín, 35010 Las Palmas de Gran Canaria, Spain; nvegdia@gobiernodecanarias.org

* Correspondence: jbfuster@hsll.es; Tel.: +34-607712119

+ All the authors contributed equally to this work.

Abstract: Diabetic kidney disease (DKD) is the most frequent cause of kidney failure (KF). There are large variations in the incidence rates of kidney replacement therapy (KRT). Late referral to nephrology services has been associated with an increased risk of adverse outcomes. In many countries, when patients reach severely reduced glomerular filtration rate (GFR), they are managed by multidisciplinary teams led by nephrologists. In these clinics, efforts will continue to halt chronic kidney disease (CKD) progression and to prevent cardiovascular mortality and morbidity. In patients with diabetes and severely reduced GFR and KF, treating hyperglycemia is a challenge, since some drugs are contraindicated and most of them require dose adjustments. Even more, a decision-making process will help in deciding whether the patient would prefer comprehensive conservative care or KRT. On many occasions, this decision will be conditioned by diabetes mellitus itself. Effective education should cover the necessary information for the patient and family to answer these questions: 1. Should I go for KRT or not? 2. If the answer is KRT, dialysis and/or transplantation? 3. Dialysis at home or in center? 4. If dialysis at home, peritoneal dialysis or home hemodialysis? 5. If transplantation is desired, discuss the options of whether the donation would be from a living or deceased donor. This review addresses the determinant factors with an impact on DKD, aiming to shed light on the specific needs that arise in the management and recommendations on how to achieve a comprehensive approach to the diabetic patient with chronic kidney disease.

Keywords: chronic kidney disease; diabetic kidney disease; hemodialysis; peritoneal dialysis; home hemodialysis; kidney transplant; kidney failure; kidney replacement therapy; comprehensive conservative care 


\section{Introduction}

Chronic kidney disease (CKD), defined as the presence of markers of kidney damage or a glomerular filtration rate (GFR) $<60 \mathrm{~mL} / \mathrm{min} / 1.73 \mathrm{~m}^{2}$, for three months or more, irrespective of cause, is classified according to the categories of GFR and albuminuria [1]. Diabetic kidney disease (DKD) is described as the persistent presence of kidney injury (either by impaired glomerular filtration rate, albuminuria or histological alterations) in subjects with diabetes mellitus (DM), in the absence of signs of other forms of kidney disease. Diabetic kidney disease is a heterogeneous disease, which includes multiple and complex overlapping etiologic pathways. Its hallmarks include alterations in glomerular hemodynamics, extracellular matrix synthesis/degradation balance, inflammation, interstitial fibrosis, oxidative stress, and tubular atrophy.

Patients with DKD have an eight-fold increased risk of cardiovascular and all-cause mortality compared to those without DM and CKD [2-4]. Furthermore, DKD is the most frequent cause of kidney failure with replacement therapy (KFRT) [5], which denotes an important morbidity of this disease. Following the recent suggestions of the KDIGO Consensus Conference [6], when we refer to kidney failure (KF) we defined it as a GFR $<15 \mathrm{~mL} /$ min per $1.73 \mathrm{~m}^{2}$ or treatment by dialysis. Kidney replacement therapy (KRT) may consist of either the realization of a renal transplant or the initiation of dialysis therapy.

For the evaluation of those patients who are candidates to receive a renal transplant, there are guidelines to guide the decision making process regarding the convenience of transplantation and the appropriate time to perform it [7]. On the other hand, deciding the appropriate time to initiate dialysis treatment is not a simple task as there are a number of factors that must be taken into account. It is widely accepted that the GFR level alone should not be used as a reason to start KRT, and that signs and symptoms associated with KF should be considered [8].

Based on the above, it is important to educate the healthcare community about the benefits of a referral protocol for patients with progressive kidney function decline, since late referral to nephrology services has been associated with an increased risk of adverse outcomes [9]. For instance, in many countries, when patients present with severely reduced GFR (CKD G4), they are evaluated by multidisciplinary teams led by nephrologists. The importance of this approach is to try to predict which patients have a greater risk of mortality and which are more likely to progress to KF. The multidisciplinary strategy seeks to halt the progression of CKD and to intensify the prevention of mortality and cardiovascular morbidity. In addition to these, the control of factors associated with kidney disease which play a role in its course and prognosis (i.e., anemia, bone and mineral disorders, hydro-electrolytic alterations) is becoming more relevant. Glycemic control in diabetic patients with CKD presents an added difficulty due to the need for dose adjustment of several hypoglycemic drugs, including contraindications in some cases.

In this review we will address the factors that influence CKD in the patient with DM, including those that predict the occurrence of cardiovascular events and progression to kidney failure in DKD. The aim is to shed light on the specific needs that arise in the management of DKD and recommendations on how to achieve a comprehensive approach, either conservatively or through KRT. For this, the role of the nursing team as well as the collaboration between nephrologists, endocrinologists, vascular surgeons, general surgeons, interventional radiologists, nutritionists, psychologists and physical exercise specialists, among others, will be of great importance.

\section{Delaying the Progression of Diabetic Kidney Disease in Patients with CKD G4}

Due to its complex pathogenesis, DKD presents a wide clinical variability. The incidence rate of KF in type $2 \mathrm{DM}$ (T2DM) is $0.29 \%$ at 10 years and $0.74 \%$ at 20 years from the diagnosis of diabetes [10], while for type 1 diabetes mellitus (T1DM) it is 2.5 per 1000 person-years [11]. However, $40 \%-53 \%$ of diabetics have mild renal disease [12,13]. Additionally, the rate of estimated glomerular filtration rate (eGFR) decline is more rapid (loss $>3 \mathrm{~mL} / \mathrm{min} / 1.73 \mathrm{~m}^{2}$ per year) in DM than in healthy individuals, particularly in patients 
with a long duration of diabetes (more than 10 years), severely increased albuminuria, or low baseline eGFR [14]. Still, variability is high. A previous study analyzing the evolution of kidney function in T2DM showed that $28 \%$ of patients presented no decline, $56 \%$ of patients showed a moderate decline $\left(-4 \mathrm{~mL} / \mathrm{min} / 1.73 \mathrm{~m}^{2} \leq\right.$ annual decline $\left.<0 \mathrm{~mL} / \mathrm{min} / 1.73 \mathrm{~m}^{2}\right)$ and $15 \%$ of them presented severe decline (annual decline $<-4 \mathrm{~mL} / \mathrm{min} / 1.73 \mathrm{~m}^{2}$ ) [12].

Unfortunately, the traditionally employed clinical biomarkers, although very useful in the diagnosis and long-term follow-up of the disease, are usually not sensitive enough to detect early kidney injury. To illustrate, the absence of albuminuria does not exclude the presence of diabetic kidney injury or subclinical renal damage [15]. On the other hand, a benefit in the treatment of albuminuria cannot be excluded either, despite not achieving the desired goal [16], since in CKD patients: (a) the risk of kidney events increases in association with moderately increased albuminuria (A2), and the increment is even further with severely increased albuminuria (A3); (b) the risk of cardiovascular events is elevated in those with moderately and severely increased albuminuria; and (c) all-cause mortality is increased in subjects with a GFR lower than $30 \mathrm{~mL} / \mathrm{min} / 1.73 \mathrm{~m}^{2}$ independently of albuminuria [17]. Moreover, DKD patients are more susceptible to acute kidney injury (AKI), which might contribute to interstitial fibrosis. In a cohort of 4082 patients with diabetes, single or repetitive episodes of AKI significantly increased the risk of developing advanced CKD [18].

Numerous risk factors (Table 1) have been identified for the development and progression of DKD. Hence, interindividual variability is the result of the interaction between sociodemographic and clinical risk factors, as well as adequate glycemic and blood pressure control.

Table 1. CKD progression risk factors in DKD.

\begin{tabular}{cc}
\hline Modifiable & Non-Modifiable \\
\hline Socioeconomic factors & Duration of diabetes \\
\hline Hyperglycemia & Familial and genetic factors \\
\hline Hypertension & Autonomic neuropathy \\
\hline Lipids & \\
\hline Diet & \\
\hline Correcting bicarbonate & \\
\hline Obesity & \\
\hline Drug and procedure toxicity & \\
\hline Urinary infections & \\
\hline Anemia &
\end{tabular}

\subsection{Duration, Socioeconomic Factors and Familial and Genetic Factors}

As mentioned above, one of the most determinant factors in CKD progression is the time course of diabetes. Cumulative risk of KFRT was $0.29 \%$ at 10 years and $0.74 \%$ at 20 years from diagnosis of T2DM [10]. Studies have demonstrated that a low socioeconomic status is associated with increased prevalence of DM, hypertension, and CKD [19].

The risk of developing DKD has a polygenetic component [20-22]. Diabetic patients with a first-degree relative with DKD have a substantially greater risk of developing DKD compared with those who do not have an affected relative [23]. Isolating a definitive causal pathway has proved to be elusive because there is no simple Mendelian inheritance and the interplay of several genes is likely involved and may differ between populations [24-26].

\subsection{Hyperglycemia}

Hyperglycemia is an important risk factor for the progression of albuminuria in diabetic subjects; however, its influence is more modest in the progression to kidney failure 
than the effect exerted by hypertension, hypercholesterolemia and genetic factors [14]. Among people with DM, studies suggest that the effect of more intensive glycemic control was associated with a reduction in albuminuria but it did not reduce significantly clinical kidney end-points, including doubling of serum creatinine, KFRT, and death from renal disease $[27,28]$. A review of the DOPPS study by Ramirez et al. showed a U-shaped association between $\mathrm{HbA} 1 \mathrm{c}$ and all-cause mortality in DM-hemodialysis patients, showing the lowest death rates in association with high HbA1c levels (7 to 7.9\%) [29]. The European Best Practice Guidelines (EBPG) advise against tighter glycemic control if this leads to severe hypoglycemic episodes, while at the same time it recommends tightening glycemic control when $\mathrm{HbA1C}$ values are $>8.5 \%(69 \mathrm{mmol} / \mathrm{mol})$ [30]. A high-quality systematic review demonstrated a lack of benefit of tighter glycemic control as assessed by an $\mathrm{HbA} 1 \mathrm{C}<7 \%$ (53 $\mathrm{mmol} / \mathrm{mol})$ or $7.5 \%$ (59 $\mathrm{mmol} / \mathrm{mol})$ [31], whereas it rather resulted in a risk of hypoglycemia episodes. In CKD with severely reduced GFR or KF the risk of hypoglycemia increases, among other reasons, due to an alteration in pharmacological metabolism. In order to avoid this, patients at high risk of hypoglycemia should perform their own regular monitoring of blood glucose levels through validated devices. It is important to keep in mind that below an eGFR of $30 \mathrm{~mL} / \mathrm{min} / 1.73 \mathrm{~m}^{2}$, the shortening of erythrocyte life biases the measurement of low $\mathrm{HbA1c}$, especially in patients receiving erythropoietin-stimulating agents.

The goals and treatments for the management of diabetes in CKD are described in the new KDIGO guidelines [32]. Cardiovascular prevention and avoiding CKD progression are the main objectives (cardio-nephroprotection). Most studies have been conducted in the early stages of DM and have excluded individuals with severely reduced GFR. In the recent years, different clinical trials have been published involving diverse pharmacological interventions with encouraging results, which have broadened their inclusion criteria for lower GFRs. The DAPA-CKD clinical trial [33] has demonstrated robust data on the role of sodium-glucose cotransporter-2 (SGLT2) inhibitors in slowing CKD progression in patients with chronic kidney disease (GFR $25-75 \mathrm{~mL} / \mathrm{min} / 1.73 \mathrm{~m}^{2}$ ), regardless of the presence or absence of diabetes, when comparing dapaglifozin with placebo (hazard ratio (HR), $0.61 ; 95 \%$ confidence interval (CI), 0.51 to $0.72 ; p<0.001)$. Dapagliflozin has proven to be effective as a cardiovascular and renal protective treatment, showing a significant decrease in mortality, in the incidence of KFRT and in suffering a decline of at least $50 \%$ in the estimated GFR (HR, $0.56,95 \%$ CI, 0.45 to $0.68, p<0.001$ ). Previously, the CREDENCE study [34] analyzed the effect of canagliflozin, another oral SGLT2 inhibitor, on renal outcomes in patients with T2DM and albuminuric CKD. The study demonstrated that canagliflozin was able to reduce by $30 \%$ the relative risk of CKD progression and cardiovascular death in diabetic patients compared with the placebo group (HR, 0.70; $95 \%$ CI, 0.59 to $0.82 ; p<0.001)$ at a median follow-up of 2.62 years. These findings show that SGLT2 inhibitors can be an effective therapy option for renal and cardiovascular protection in patients with type 2 diabetes with chronic kidney disease. Additionally, a subgroup analysis of the CREDENCE trial [35] showed that canagliflozin reduced the risk of kidney disease progression to KF in participants with eGFR $\geq 30 \mathrm{~mL} / \mathrm{min} / 1.73 \mathrm{~m}^{2}$ (HR, $0.70 ; 95 \% \mathrm{CI}, 0.54$ to 0.91 ), whose effects were maintained in those subjects with an eGFR $<30 \mathrm{~mL} / \mathrm{min} / 1.73 \mathrm{~m}^{2}(\mathrm{HR}, 0.67 ; 95 \% \mathrm{CI}, 0.35$ to 1.27 ; $\mathrm{p}$ interaction $=0.80)$. There was also no difference in the rate of kidney-related adverse events or AKI, associated with canagliflozin, between participants with eGFR $<30$ and $\geq 30 \mathrm{~mL} / \mathrm{min} / 1.73 \mathrm{~m}^{2}$. The results support the use and continuation of SGLT2 inhibitors until initiation of dialysis or kidney transplantation (KT).

In summary, for adequate glycemic control in the diabetic patient with $C K D$, it is important to take into account the need for lifestyle therapy through physical exercise, nutritional intervention and weight loss. The KDIGO guidelines recommend as first-line antihyperglycemic therapy the use of metformin, as long as the GFR $\geq 30 \mathrm{~mL} / \mathrm{min} / 1.73 \mathrm{~m}^{2}$ [32]. Metformin exerts an effective $\mathrm{HbA1c}$ reduction with a safe profile due to the low risk of hypoglycemia [36-38]. In addition, it has been shown to reduce weight in obese patients, 
as well as the incidence of cardiovascular events. On the other hand, SGLT2 inhibitors are also considered first-line therapy for diabetic patients with GFR $\geq 30 \mathrm{~mL} / \mathrm{min} / 1.73 \mathrm{~m}^{2}$, either in combination with metformin or when metformin cannot be used [32]. Different trials [34,39-41] have proven the cardio- and nephroprotective role of these drugs, as well as their efficacy and safety in the presence of low GFR. The guidelines recommend not starting SGLT2 inhibitors when the GFR is below $30 \mathrm{~mL} / \mathrm{min} / 1.73 \mathrm{~m}^{2}$; however, in accordance with the approach followed in the CREDENCE trial [34], in those patients who are already taking it and have a drop in GFR below $30 \mathrm{~mL} / \mathrm{min} / 1.73 \mathrm{~m}^{2}$, the SGLT2 inhibitor can be continued until initiation of kidney replacement therapy. Furthermore, when diabetic patients with CKD require additional treatment for glycemic control, or cannot use metformin and/or SGLT2 inhibitors, the KDIGO guidelines recommend glucagon-like peptide-1 receptor agonists (GLP-1 RA) as the preferred option, due to the cardiovascular and renal benefit they have proven in the recent trials [42-46]. These recommendations are in line with the ACC [47], ADA [48] and ESC/EASD guidelines [3]. GLP-1 RA have shown a $36 \%$ to $15 \%$ reduction in the risk of CKD progression, especially at the expense of improved albuminuria control. These drugs can be used up to a GFR of $15 \mathrm{~mL} / \mathrm{min} / 1.73 \mathrm{~m}^{2}$ [49]. Options recommended by KDIGO guidelines for patients with GFR $<15 \mathrm{~mL} / \mathrm{min} / 1.73 \mathrm{~m}^{2}$ are DPP-4 inhibitors, insulin, and thiazolidinediones [32]. It is important to emphasize that the choice of the most appropriate treatment for each patient should be based on the patient's preferences, comorbidities, eGFR (Table 2) and cost. Figure 1 summarizes the KDIGO Diabetes Management in CKD Guideline.

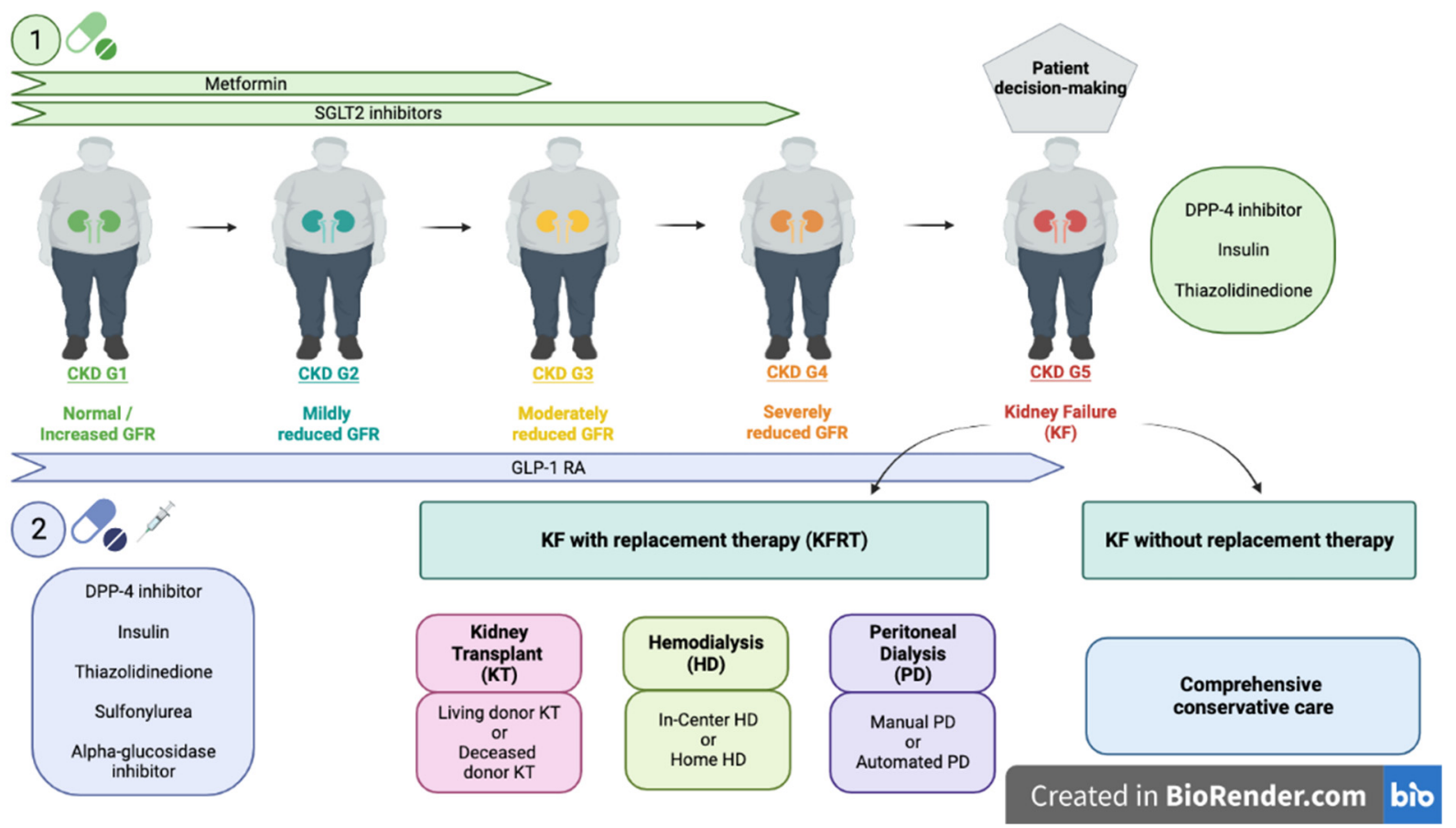

Figure 1. DKD progression and management recommendations using nomenclature recommended by Executive Summary and Glossary from a Kidney Disease: Improving Global Outcomes (KDIGO) Consensus Conference (1) and KDIGO Diabetes Management in CKD Guideline (2).

First-line antiglycemic medications (green) are metformin and SGLT2 inhibitor. As second-line therapy (purple) it is recommended to prioritize GLP-1 AR over other antiglycemic medications due to its cardiovascular and renal benefits. Other drugs that can be used are iDPP4, insulin, thiazolidinedione, sulfonylureas and alpha-glucosidase inhibitor. In patients with KF, iDPP4, insulin and thiazolidinedione are more suitable options. CKD, Chronic kidney disease; GFR, Glomerular filtration rate; SGLT2, Sodiumglucose cotransporter-2; GLP-1 RA, Glucagon-like peptide-1 receptor agonists; DPP-4, Dipeptidyl peptidase-4; KF, Kidney failure; KRT, Kidney replacement therapy; G1: GFR 


\begin{abstract}
$\geq 90 \mathrm{~mL} / \mathrm{min}$ per $1.73 \mathrm{~m}^{2}$; G2: GFR $60-89 \mathrm{~mL} / \mathrm{min}$ per $1.73 \mathrm{~m}^{2}$, G3a: GFR $45-59 \mathrm{~mL} / \mathrm{min}$ per $1.73 \mathrm{~m}^{2}$; G3b: GFR $30-44 \mathrm{~mL} / \mathrm{min}$ per $1.73 \mathrm{~m}^{2}$; G4: GFR $15-29 \mathrm{~mL} / \mathrm{min}$ per $1.73 \mathrm{~m}^{2}$; G5: GFR $<15 \mathrm{~mL} / \mathrm{min}$ per $1.73 \mathrm{~m}^{2}$ or treated by dialysis. (1) A. S. Levey et al., "Nomenclature for kidney function and disease: executive summary and glossary from a Kidney Disease: Improving Global Outcomes (KDIGO) consensus conference," Journal of Nephrology, vol. 33, no. 4. pp. 639-648, 2020. (2) I. H. de Boer et al., "Executive summary of the 2020 KDIGO Diabetes Management in CKD Guideline: evidence-based advances in monitoring and treatment," Kidney Int., vol. 98, no. 4, pp. 839-848, Octorber 2020.
\end{abstract}

Table 2. Usual and renal function-adjusted doses of Metformin, SGLT2 inhibitors and GLP-1 RA.

\begin{tabular}{|c|c|c|}
\hline Drug & Dose & CKD Adjustment \\
\hline \multicolumn{3}{|l|}{ Metformin } \\
\hline Immediate release & $\begin{array}{l}\text { Initial } 500-850 \mathrm{mg} \text { once daily } \\
\text { Titrate upwards by } 500-850 \mathrm{mg} / \mathrm{d} \text { every } \\
\text { seven days until maximum dose }\end{array}$ & \multirow{2}{*}{$\begin{array}{c}\text { For an eGFR between } 45-59 \mathrm{~mL} / \mathrm{min} / 1.73 \mathrm{~m}^{2} \text {, dose } \\
\text { reduction if risk of hypoperfusion and } / \text { or hypoxemia. } \\
\text { Halve the dose if eGFR } 30-45 \mathrm{~mL} / \mathrm{min} / 1.73 \mathrm{~m}^{2} \\
\text { Discontinue if eGFR }<30 \mathrm{~mL} / \mathrm{min} / 1.73 \mathrm{~m}^{2}\end{array}$} \\
\hline Extended release & $\begin{array}{c}\text { Initial } 500 \mathrm{mg} \text { daily } \\
\text { Titrate upwards by } 500 \mathrm{mg} / \mathrm{d} \text { every } \\
\text { seven days until maximum dose }\end{array}$ & \\
\hline \multicolumn{3}{|l|}{ SGLT2 inhibitors } \\
\hline Empagliflozin & $10-25 \mathrm{mg}$ once daily & $\begin{array}{c}\text { No dose adjustment if eGFR } \geq 45 \mathrm{~mL} / \mathrm{min} / 1.73 \mathrm{~m}^{2} \\
\text { Discontinue if eGFR persistently }<45 \mathrm{~mL} / \mathrm{min} / 1.73 \mathrm{~m}^{2}\end{array}$ \\
\hline Canagliflozin & 100-300 mg once daily & $\begin{array}{c}\text { No dose adjustment if eGFR }>60 \mathrm{~mL} / \mathrm{min} / 1.73 \mathrm{~m}^{2} \\
100 \mathrm{mg} \text { daily if eGFR } 30-59 \mathrm{~mL} / \mathrm{min} / 1.73 \mathrm{~m}^{2} \\
\text { Avoid initiation with eGFR }<30 \mathrm{~mL} / \mathrm{min} / 1.73 \mathrm{~m}^{2} \\
\text { Discontinue when initiating dialysis }\end{array}$ \\
\hline Dapagliflozin & 5-10 mg once daily & $\begin{array}{l}\text { No dose adjustment if eGFR } \geq 45 \mathrm{~mL} / \mathrm{min} / 1.73 \mathrm{~m}^{2} \\
\text { Not recommended if eGFR }<45 \mathrm{~mL} / \mathrm{min} / 1.73 \mathrm{~m}^{2} \\
\text { Contraindicated with eGFR }<30 \mathrm{~mL} / \mathrm{min} / 1.73 \mathrm{~m}^{2}\end{array}$ \\
\hline
\end{tabular}

\title{
GLP-1 RA
}

\begin{tabular}{ccc}
\hline Dulaglutide & $0.75 \mathrm{mg}$ and $1.5 \mathrm{mg}$ once weekly & $\begin{array}{c}\text { No dosage adjustment } \\
\text { Use with eGFR }>15 \mathrm{~mL} / \mathrm{min} / 1.73 \mathrm{~m}{ }^{2}\end{array}$ \\
\hline $\begin{array}{c}\text { Exenatide } \\
\text { (Extended-release) }\end{array}$ & $10 \mu \mathrm{g}$ twice daily & Use with $\mathrm{CrCl}>30 \mathrm{~mL} / \mathrm{min}$ \\
\hline Liraglutide & $0.6 \mathrm{mg}, 1.2 \mathrm{mg}$, and $1.8 \mathrm{mg}$ once daily & $\begin{array}{c}\text { No dosage adjustment } \\
\text { Limited data for severe CKD }\end{array}$ \\
\hline $\begin{array}{c}\text { Lixisenatide } \\
\text { (injection) }\end{array}$ & $10 \mu \mathrm{g}$ and $20 \mu \mathrm{g}$ once daily & $\begin{array}{c}\text { No dosage adjustment } \\
\text { Limited data for severe CKD }\end{array}$ \\
\hline $\begin{array}{c}\text { Semaglutide } \\
\text { (oral) }\end{array}$ & $0.5 \mathrm{mg}$ and $1 \mathrm{mg}$ once weekly & $\begin{array}{c}\text { No dosage adjustment } \\
\text { Limited data for severe CKD }\end{array}$ \\
\hline
\end{tabular}

Abbreviations: CKD: chronic kidney disease; $\mathrm{CrCl}$, creatinine clearance; eGFR, estimated glomerular filtration rate; SGLT2, sodium-glucose cotransporter-2; GLP-1 RA, glucagon-like peptide-1 receptor agonists. For SGLT2 inhibitors, the adjusted doses correspond to the indications approved by the U.S. Food and Drug Administration (FDA).

\subsection{Hypertension}

Many authors recommend a blood pressure (BP) target of $140 / 90 \mathrm{mmHg}$ for patients with DM, regardless of CKD [1]. Others suggest a target of 130/80 $\mathrm{mmHg}$ in the presence of moderately to severely increased albuminuria (A2 and A3) [50]. In patients aged 75 years or older, it is maintained at $<150 / 90 \mathrm{mmHg}$ regardless of GFR category (G1-G5) and the presence of DM, and at $<140 / 90 \mathrm{mmHg}$ if there are no adverse events such as orthostatic 
hypotension [51]. In a meta-analysis of 157 randomized controlled trials comparing BPlowering agents in adults with type $2 \mathrm{DM}$ and CKD, no blood pressure-lowering strategy was superior to placebo regarding survival. Treatment with angiotensin-converting enzyme inhibitors (ACEi) and angiotensin-II receptor blockers (ARB) showed the greatest efficacy for the prevention of KFRT; however, only the ARB was significantly better than placebo. The effects on BP did not differ between treatment regimens, demonstrating that pharmacological effects are independent of BP lowering. No regimen significantly increased hyperkalemia or AKI, although combined treatment with ACEi plus ARB led to borderline increases in estimated risks of these harms [52]. For patients who develop hyperkalemia, measures are available to control potassium levels, such as moderating potassium intake, diuretic initiation, use of sodium bicarbonate in those with metabolic acidosis, and co-administrating gastrointestinal cation exchangers.

Finally, and in reference to the RAAS axis blockade, in patients with an $\mathrm{eGFR}<30 \mathrm{~mL} / \mathrm{min} / 1.73 \mathrm{~m}^{2}$, the European guidelines advise starting treatment with ACEi if there is a cardiac indication, but also advise to stop it if there are side effects. If renal function progresses to an eGFR $<15 \mathrm{~mL} / \mathrm{min} / 1.73 \mathrm{~m}^{2}$, due to the risk of a cardiovascular event or the initiation of dialysis, it is advisable to evaluate its interruption in an attempt to delay the start of dialysis [30].

Another drug of interest is finerenone (non-steroidal antagonist of the mineralocorticoid receptor). In the FIDELIO-DKD study, it shows a decrease in the incidence of cardiovascular events ( $\mathrm{HR}, 0.86 ; 95 \% \mathrm{CI}, 0.75$ to $0.99 ; p=0.034$ ), as well as a decreased in kidney events (HR, $0.82 ; 95 \%$ CI, 0.73 to $0.93 ; p=0.001)$ in patients with GFR $25-75 \mathrm{~mL} / \mathrm{min} / 1.73 \mathrm{~m}^{2}[53,54]$.

\subsection{Lipids}

People with diabetes and severely reduced GFR typically have significant hypertriglyceridemia, high LDL and low HDL cholesterol levels [55]. These abnormalities tend to be more pronounced when severe albuminuria is present, and they diminish with progression to KF and dialysis [14]. The SHARP study [56] (average eGFR $27 \mathrm{~mL} / \mathrm{min} / 1.73 \mathrm{~m}^{2}$ ) found that the association of statin plus ezetimibe significantly reduced major atherosclerotic events. The relative effect was similar when diabetes was present ( $23 \%$ of 9438 patients had diabetes). This study did not detect any effect of lipid-lowering therapy on the frequency of doubling of baseline serum creatinine concentration or progression to KFRT [57]. The role for dyslipidemia in the development and progression of DKD is unclear. Joint guidelines of the Association of British Clinical Diabetologists and the Renal Association recommend that hypolipidemic treatment with statins should be considered for all patients with CKD stages 3-5 and DKD (mainly because of cardiovascular risks). Fibrates should rarely be considered for treatment in this population [58]. No effect on CKD progression has been observed by the use of PCSK-9 inhibitors [59].

\subsection{Diet}

Long-term high protein intake accelerates structural and functional injury in models of DKD, whereas low protein provides kidney protection [14]. Nevertheless, there are no observational data in humans that unequivocally support this role of dietary protein. Yet it is accepted that a diet with uncontrolled intake of calories, protein, sodium, and phosphates exacerbates clinical metabolic alterations related to CKD G4-G5; hence, appropriate dietary-nutritional therapy may delay the need for KRT. It is known that G4-G5 CKD is characterized by a dysbiosis of the intestinal microbiota, which contributes to uremic intoxication and cardiovascular damage. Low-protein nutrition therapy associated with adequate fiber intake can counteract dysbiosis and reduce uremic toxins' production [60]. Increasing evidence suggests that focusing on dietary intake patterns, rather than individual nutrient intake per se, offers an insightful approach to examine and identify the role of diet in CKD [61]. 
Adequate salt intake has been associated with reduced BP and improved control of albuminuria. In fact, sodium intake is the single most important factor in CKD progression and the control of hypertension. Dietary sodium is known to significantly modulate the nephroprotective response to RAAS blockade, while a persistent proteinuria is found in those subjects with high dietary sodium intake [62]. The increased glucose uptake in the proximal tubule, due to hyperglycemia, generates an enhanced sodium reabsorption through the SGLT2 channel. Secondary to this, sodium delivery to the distal tubule is reduced and sensed as ineffective circulating volume. This situation triggers a series of mechanisms that lead to hemodynamic changes at the glomerular level, resulting in podocyte injury [63].

\subsection{Metabolic Acidosis}

A recent meta-analysis including 14 trials and 1394 participants [64] found that treating metabolic acidosis with oral alkaline supplementation, or reducing dietary acid intake, increases serum bicarbonate levels (mean difference $3.33 \mathrm{mEq} / \mathrm{L}, 95 \% \mathrm{CI}, 2.37$ to 4.29) and results in a slower decline in eGFR (13 studies, 1329 patients, mean difference $-3.28 \mathrm{~mL} / \mathrm{min} / 1.73 \mathrm{~m}^{2}, 95 \% \mathrm{CI}, 24.42$ to 22.14 ), along with a reduced risk of progression to KF (relative risk, $0.32 ; 95 \% \mathrm{CI}, 0.18$ to 0.56 ).

\section{Prediction of Cardiovascular Events and Progression to Kidney Failure in Patients with DKD and Severely Reduced GFR}

Efforts to prevent and treat DKD progression factors with the available measures have not reduced the morbidity and mortality of these patients to the desired level.

Different epidemiological studies have revealed the heterogenicity of DKD features within different rates of CKD progression. Between 19\% and 31\% of patients may have a non-linear GFR decline [65]. In addition, beyond the classic albuminuric presentation, a non-proteinuric phenotype is described as representing up to $40 \%$ of DKD in type 2 diabetics with eGFR $<60 \mathrm{~mL} / \mathrm{min} / 1.73 \mathrm{~m}^{2}$. Typically, in these situations the histological injury is at the vascular and interstitial compartments rather than in the glomerular area. This presentation does not seem to depend on glycemic control and is associated with higher CV risk [66].

The use of predictive models of KF such as the kidney failure risk equation (KFRE), or those associated with the histological classification of diabetic nephropathy score (D-Score) can be useful. However, in DKD these tools present a lower predictive value than in the general cohort of CKD (c-statistic: $0.80(0.74-0.86))$ [67].

In the prediction of $\mathrm{CV}$ events, screening for coronary disease in asymptomatic patients is not indicated. Nonetheless, the indication for coronary arteriography should not be restricted, when necessary, despite the risk of kidney injury exacerbation. A carotid and/or femoral ultrasound should be considered to assess the presence of atheromatous disease in patients without cardiovascular disease, as it predicts CV events $[3,68,69]$.

The prediction of $\mathrm{CV}$ events and CKD progression can be interfered with by different factors. The incorporation of new drugs to CKD G4, which go beyond glycemic control, with a double objective (cardio and nephro-protection), opens up hope for the future of patients with DKD, in whom the risk of suffering from any of the two events is very high.

\section{Patient Decision-Making}

The transition from CKD G4 to KF (G5) represents a vulnerable period for the patient with elevated risk of adverse events and multiple physiologic and psychosocial changes. It is also a period in which nephrologists must make decisions together with the patient and family members [70]. In patients with diabetes, it may be even more complex because there are usually many comorbidities. Also, there are substantial variations in how this transition is run in different units [71].

Patient education and involvement make this transition easier. A meta-analysis found that self-management support interventions may improve self-management activities [72]. These interventions help patients to better understand KF, compare available treatments 
and share information with family members [73]. They can be delivered face-to-face as one-to-one or group-based programs or via digital platforms by members of health care teams. The best approach is to tailor the intervention to the individual's preferences [74]. Few studies have evaluated the utility of self-management education in patients with DKD, but systematic reviews in the population with diabetes have shown a long-term reduction of clinical risk factors [75].

Effective education should cover the necessary information for the patient and family members to answer the following questions [76]: 1. Should I go for KRT or not? 2. If the answer is KRT, dialysis and/or transplantation? 3. Dialysis at home or in-center? 4. If dialysis at home, peritoneal dialysis or home hemodialysis? 5. If transplantation is desired, discuss the question if deceased or living donor?

When kidney function is failing, discussion of the different KRT modalities and selection of a specific therapy should be started promptly [77]. There is not a specific eGFR value for initiating dialysis; rather, it is necessary to offer individualized care. As will be discussed below, a reasonable effort must be made to avoid tunneled catheters as primary vascular access. As life expectancy in some patients is low, persisting efforts to create a vascular access might cause a substantial decrease in their quality of life [30].

If there are no contraindications for KRT (patient candidacy or eligibility profile), it is not clear in subjects with diabetes whether the KRT modality (different modalities of hemodialysis (HD) or peritoneal dialysis (PD)) selected as first-choice has a major impact on outcomes, metabolic profile, diabetes complications and technique survival of the KRT. Therefore, the patient's preference in selecting KRT should be the driving force for kidney replacement modality. Obviously, patients should be provided with unbiased information [30]. Education on the different options of transplantation and their expected outcomes for patients with diabetes is recommended. Also, information about combined kidney-pancreas transplantation must be included for patients with T1DM and some with T2DM $[78,79]$.

Physicians have the responsibility for initiating and guiding through the advance care planning process. Information needs to be personalized, integrating how their medical and interventions would affect their life and relationships most [80].

\section{Kidney and Kidney-Pancreas Transplantation in Patients with DKD}

Kidney transplantation (KT) is the treatment of choice for the diabetic patient with KFRT, as it increases quality of life and prolongs long-term patient survival [81]. In spite of the increased CV risk in the diabetic patient compared to non-diabetic patients, this improvement in long-term results can even be greater in patients with diabetes as a consequence of the poor results of patients remaining on dialysis [82]. According to Wolfe et al. [81], KT can be associated with a mean increase in life expectancy of 11 years, when compared to the diabetic patient remaining on the waiting list. This survival benefit is mainly due to the significant reduction in CV risk associated with KT, compared to remaining on dialysis [83].

The timing for KT is a relevant aspect to consider. Many studies demonstrate that transplantation in the predialysis phase (preemptive transplantation) is associated with an increased patient survival, both in diabetic and non-diabetic patients [79,84-86]. Even more, some studies suggest an increased graft survival [87], although others do not find differences, especially in deceased donor KT [88]. For these reasons, an early referral to the nephrologist for a KT evaluation with enough time for preemptive transplantation is crucial [89]. Some authors recommend referral to the transplant team when eGFR drops below $30 \mathrm{~mL} / \mathrm{min} / 1.73 \mathrm{~m}^{2}$ [84] in order to complete evaluation and include the patient in the waiting list when it is below $20 \mathrm{~mL} / \mathrm{min} / 1.73 \mathrm{~m}^{2}$. Living donor $\mathrm{KT}$ has the added advantage of the reduced waiting time, thus increasing the possibilities to avoid dialysis initiation [90].

Combined kidney-pancreas transplantation in patients with T1DM and KF brings an additional benefit associated with the normalization of glucose metabolism, the slowing 
down of progression of organ damage induced by diabetes (mainly retinopathy, neuropathy, nephropathy and cardiovascular damage), as well as a significant improvement in quality of life [78].

Patients with diabetes have an increased surgical risk related to the severity of CV disease. As a consequence, they have a reduced survival rate compared with patients without diabetes $[82,91]$. This must be taken into account to individualize each patient, considering the risk/benefit ratio of the kidney and/or kidney-pancreas transplantation. A careful evaluation should be done to discard asymptomatic disease (mainly cardiovascular) that might add an excessive risk for surgery and immunosuppression.

\section{Peritoneal Dialysis in Patients with DKD}

In 2001, the NKF-KDOQI guidelines published their recommendations, indications and contraindications of peritoneal dialysis (PD) [92] (Table $3 \mathrm{a}, \mathrm{b}$ ). In the last decade, for ERBP 2010 [93], KDIGO 2012 [1] and NICE [94], the only factors considered for eligibility in PD were: not having absolute contraindications, having an intact peritoneal membrane, and to have freely chosen this option [95]. There are two modalities of PD, continuous ambulatory peritoneal dialysis (CAPD) and automated peritoneal dialysis (APD), and both can be performed by diabetic patients.

Table 3. Contraindications of PD: (a) according to the clinical practice recommendations of the NKF-KDOQI (Golper TA, Am J Kidney Disease 2001); (b) other contraindications mentioned in the literature.

(a)

\section{Absolute}

Documented loss of peritoneal function or extensive abdominal adhesions limiting dialysate flow.

Patients who have physical or mental disabilities in the absence of a suitable assistant.

Patients with uncorrectable mechanical defects that prevent effective PD or increase the risk of infection:

Surgically irreparable hernia.

Omphalocele.
Gastroschisis.
Diaphragm hernia.
Bladder exstrophy.

(b)

\begin{tabular}{cc}
\hline Absolute & Relative \\
\hline Medical: & Medical: \\
\hline Large abdominal aortic aneurysm. & Abdominal adhesions. \\
\hline Previous major abdominal surgery and with large abdominal scars. & Planned abdominal surgery. \\
\hline Severe lung disease with poor lung function. & Ostomies, colostomy, ileostomy. \\
\hline
\end{tabular}

Severe gastroparesis.

Polycystic kidney disease (very large kidneys). Intestinal cancer.

Diseases that limit manual dexterity or upper limb amputations.

Presence of ventriculoperitoneal communication.

Social: Social:

The place of residence does not allow it.

Work or employment does not allow it.

Recent intra-abdominal bodies (e.g., less than 4 months, vascular prosthesis, ventriculopertioneal shunt).

Peritoneal leaks.

Limitations due to body size dialysis dose.

Active inflammatory or ischemic bowel disease.

Abdominal wall or skin infection.

Morbid obesity (in small individuals). Severe malnutrition.

Frequent episodes of diverticulitis. 
As peritoneal dialysis fluid contains glucose, it must be a factor to take into account when considering PD for diabetic patients. Glycemic control is essential, and the levels of glucose, hemoglobin, and the time of interaction between both, influence the changes in HbA1c. Poor glycemic control appears to be associated with increased morbidity and mortality [96-99]; however, the relationship between $\mathrm{HbA1c}$ levels and morbidity and mortality is controversial. On the one hand, its association is related with higher mortality rates [96], but on the other hand, it is known that there is no association in the first two years of PD [100].

In 2012, a meta-analysis [101] concluded that the use of intraperitoneal (IP) insulin provided adequate glycemic control, which appears to be superior to that observed with subcutaneous (SC) insulin. However, alterations in plasma lipids by IP administration possibly contribute to an increased CV risk. In this regard, no references have been found in PUBMED in recent years.

As compared with conventional hemodialysis, PD is associated with a slower decrease in residual kidney function (RKF) [102]. An observational study showed that glycemic control was not associated with changes in RKF during the first year on PD [103]. However, the slope of loss of RKF is more pronounced in patients with diabetes, especially in the first year, diminishing in the following year and, starting from a higher initial urine production, they also experience a greater decrease in it [104].

The associated multi-comorbidity that affects diabetic and non-diabetic patients alike may be present from the beginning of treatment, and the numerous barriers that may arise over time (Table 4) must be overcome by complying with international evidence-based clinical guidelines, with measures that contribute to reduce the failure of the technique, as well as by providing care, psychological advice, and assistance for dialysis at home [105-113].

Table 4. Barriers that may arise over time patients with PD.

\begin{tabular}{|c|}
\hline Aging. \\
\hline Frailty. \\
\hline Overweight. \\
\hline Loss of autonomy to self-care. \\
\hline Visual, auditory and cognitive problems. \\
\hline Psychosocial and social problems such as isolation. \\
\hline Burnout of the patient or caregiver. \\
\hline Inflammation and malnutrition. \\
\hline Loss of residual kidney function (RKF). \\
\hline Volume overload and cardiovascular disease (CVD). \\
\hline Stroke and peripheral arterial disease (PVD). \\
\hline Metabolic syndrome secondary to glucose absorption. \\
\hline Alterations in the functionality of the peritoneal membrane. \\
\hline
\end{tabular}

\section{In-Center Hemodialysis in Patients with DKD. Vascular Access Problems in Patients with Diabetes}

There are no specific contraindications for performing HD in patients with DKD. However, patients with diabetes may present important complications to be taken into account. These complications are related to atherosclerosis and cardiomyopathy, which cause most morbidity and mortality, as well as problems with the vascular access [114]. The excessive cardiac morbidity and mortality of patients with diabetes seem to be mediated via ischemic disease rather than progression of cardiomyopathy while on dialysis therapy. Foley et al. found that only $16 \%$ of 432 patients with diabetes at the start of dialysis had normal left ventricular size and systolic function [115]. These cardiological problems 
condition tolerance to HD sessions, favoring intradialytic hypotension [116], which is the most frequent complication of the HD technique.

In 1972, Chavanian wrote: " . . there is little prospect of improving the quality of life for patients with diabetic nephropathy and renal failure, and survival is likely to be short. Dialysis for such patients may be considered as a palliative measure with little prospect of long-term survival" [117]. Since then, fortunately, things have improved a lot, but the mortality of patients with diabetes on HD continues to be elevated $[118,119]$.

There is a series of specific problems in patients with diabetes, such as intradialytic hypotension [116], anemia, altered parathormone activity etc. Among them, we want to highlight glycemic control [120] and vascular access-related problems [121,122].

In patients with diabetes on hemodialysis, blood glucose levels are associated not only with factors related to KF but also with HD. In patients on HD, predialysis glucose levels are used instead of fasting glucose. Glycosylated hemoglobin ( $\mathrm{HbA1c}$ ) values tend to be lower in HD patients, indicating a glycemic control apparently better than what they actually have $[123,124]$. There are several reasons for this, such as that the life span of erythrocytes is shortened, the blood loss occurring during HD therapy, and the use of erythropoiesis-stimulating agents (ESAs). For these reasons, some guidelines recommend using glycated albumin (GA) [125]. Also, glycemic control in patients on HD differs widely between non-dialysis and dialysis days. HD can also induce hyperglycemia. As glucose diffuses from plasma to dialysis fluid, glucose levels decrease during the dialysis session and increase after HD. However, also, plasma insulin is removed during the HD session due to its adsorption on the dialyzer membrane. According to these conditions, both HD-induced hypoglycemia and HD-associated hyperglycemia can occur during and after HD sessions [126].

Since a considerable number of hemodialysis patients are diabetic and elderly, the vascular access issue is one of the major challenges for nephrologists and vascular surgeons. Both the creation and proper development of the vascular access are crucial for adequate dialysis treatment, while ensuring adequate longevity of use, sufficient blood flow to achieve the necessary dialysis dose, and a minimal complication rate [127]. However, the presence of DM is one of the main risk factors for vascular access failure, as it causes atherosclerosis in small and medium-sized vessels, resulting in calcification and arterial stenosis [128]. Calcified atherosclerosis often implies inadequate flow, as the arteries are unable to dilate. Thus, compared with patients without diabetes, incident diabetic patients on HD have worse arteriovenous fistula (AVF) patency rates [121] and a higher risk of AVF failure [122]. A meta-analysis [122], with 23 papers analyzed, which were published between 1998 and 2016, regarding AVF complications in the diabetic population, studied the outcomes in 930 diabetic subjects with AVF. The work revealed that patients with diabetes have a higher rate of AVF failure compared to non-diabetics. The authors argue several reasons for this finding. First, diabetic disease has a high tendency for platelet aggregation and a higher prevalence of thrombotic formations [129]. In part, this is due to the release of bioactive substances as a consequence of hyperglycemia and glycosylation end products, which injure the internal wall of blood vessels. Associated with this, patients with diabetes have a higher prevalence of atherosclerosis, as well as a greater severity of vascular lesions. To these features must be added that the patient with diabetes (mainly type 2) is more exposed to numerous blood extractions, and intravenous infusions and punctures during the course of the disease.

A study by Gołębiowski et al. [130] analyzed 166 patients with DKD who had a new AVF created and analyzed outcomes and complications according to the different types of fistulas created. More than $80 \%$ of the patients were T2DM patients. Atherosclerotic changes were observed at the level of the forearm in $60 \%$ of diabetic subjects. Among these patients, in about half of them an adequate forearm AVF could be created in the first procedure, while in the other half an additional intervention was necessary. Despite this, in only $10 \%$ of all diabetics $(n=166)$ did atherosclerosis pose a significant obstacle to AVF creation, despite requiring additional procedures. Regarding the site of AVF creation, the 
authors agree that the preferred site is the wrist region; however, in patients with diabetes, due to atherosclerotic changes, the elbow area is frequently used.

Another important study [131] analyzing 347 AVFs and 799 vascular access procedures, comparing diabetic patients with non-diabetic patients, observed that the number of deceased patients, of those who had been switched to peritoneal dialysis, who had undergone surgical closure of the AVF or who had been switched to hemodialysis via indwelling central venous catheter, was higher in patients with diabetes. In addition, probably in relation to vascular complications, non-diabetic subjects had been more frequently kidney transplanted. Also, probably in association with a high comorbidity prior to the creation of the AVF that led to its creation at the elbow, these patients (with localized AVF at the elbow) had a higher mortality and a greater number of active AVF closures. In this study, $74 \%$ of diabetics required an AVF at the elbow, compared to $32 \%$ in non-diabetic patients. The selection of the type of fistula should take into account the shorter life expectancy of some diabetic patients. In the study just described, at the end of the follow-up period (mean follow-up $31 \pm 19.3$ months), only $20.5 \%$ of diabetic patients were alive with a functioning vascular access in the same extremity, compared to $44.6 \%$ of non-diabetic patients. For this reason, the authors suggest creating vascular access in the elbow region if limited survival on hemodialysis is anticipated. This allows a higher dose of dialysis to be administered and a better quality of life than non-maturable peripheral anastomoses. A review by the same author [132] provided data from his experience. Within five years, 748 underwent primary AV fistula construction. The author indicates that $15 \%$ of diabetic patients (compared to $2 \%$ of non-diabetic patients) had contraindications to the performance of any vascular access due to cardiovascular comorbidities, such as peripheral ischemia or congestive heart failure. Of all the patients, $24 \%$ were diabetic. As in the previous study, diabetic patients required the creation of the AVF at the elbow in a higher proportion than non-diabetic patients (76\% vs. $38 \%)$.

As a recommendation, it is important to bear in mind that a detailed and systematic preoperative study helps in the choice of the anatomical area to be preferred for the first AVF, since adequate maturation of the AVF requires a healthy vascular tree, free of calcifications. If the arteries are calcified, the elbow should be the first choice for AVF creation, as calcification at this level is less pronounced than in the wrist arteries. However, these present an increased risk of steal syndrome, as involvement of arteries distal to the elbow results in increased peripheral resistance, diverting most of the flow into the fistula, leading to hand ischemia [133]. Jennings et al. described that proximal radial arterybased AVFs offer excellent functional patency with a low risk of dialysis access-related steal syndrome [134]. Given the increased risk of infections and the complexity of their treatment in the diabetic patient, AVF should be the vascular access of first choice for most diabetic patients, and mainly if they are elderly patients, so the use of central venous catheters is usually an alternative only when the AVF is to be dispensed with. However, it is a valid option in diabetic patients, as is the switch to peritoneal dialysis.

The EUDIAL group [135] reminds that for proper clinical practice the health care team should strive for the most appropriate vascular access for each patient, based on local experience, patient comorbidities, physical examination, ultrasound mapping and surgical anatomy. It further recommends that practitioners should employ, mainly in the elderly and/or diabetic population, that surgical strategy that minimizes to the maximum the complications of VA, such as AVF failure, steal syndrome and congestive heart failure [136].

\section{Home Hemodialysis in Patients with DKD}

The increased incidence and prevalence of patients with diabetes and CKD G5 who require dialysis is a challenge to optimizing accessibility to the current available kidney replacement therapy (KRT).

Home HD offers the possibility of increasing the frequency, duration of the session, tolerance, and efficacy of substitution treatment since it directly affects not only a series of very prevalent factors in patients with advanced and elderly DKD, such as BP control, ven- 
tricular hypertrophy, anemia, mineral metabolism, peripheral vascular disease, autonomic dysfunction, hemodynamic instability and nutrition but also their quality of life, with a favorable impact on survival [137-140].

International [141] clinical practice guideline for hemodialysis adequacy: 2015 update especially recommend intensive HD regimens, such as those provided by Home HD, precisely for this profile of patients in whom treatment must be individualized, with the least impact on their quality of life.

In patients with diabetes and CKD G5 on home HD, due to its comorbidities, special attention is required to its stability during medical follow-up. Also, is important to avoid major clinical or hemodynamic incidences during HD sessions, to have an adequate vascular access and commitment to self-care, as well as socio-family support that, on occasions, includes a caregiver committed to performing the Home HD and/or assisting it [142].

For patients with DKD, the absolute and relative contraindications for performing home HD [143] are the same as for the rest of the population with CKD who require KRT.

Whilst KRT offers better results, it is our obligation to offer patients with DKD the option of home HD in the informed decision-making process. We must offer them the best adequate dialysis possible, individualized and respecting their autonomy wherever their preferences are located and their lifestyle at the center of choice.

\section{Patients with DKD Who Could Benefit from Comprehensive Conservative Care}

For people with diabetes, KF is a potentially devastating condition, markedly increasing cardiovascular risk and potentially leading to premature death [4]. Patients with DKD have multiple comorbidities, suffer higher overall hospitalization, higher complication rates, and the most truncated life expectancy on dialysis compared to other patient groups of any age [3]. Many of them at the commencement of dialysis are frail, which increases both morbidity and mortality and limits the individual's ability to cope with dialysis. Functional dependence and impaired intellectual status are also poor prognostic factors [144-148]. Thus, on certain occasions, nephrologists and patients themselves find it difficult to decide whether long-term dialysis is the best choice, especially when patients have multiple comorbidities. A long term of KRT, with the absence of any prospect of resolving the clinical situation in those patients and no alternative to receive a KT, has a negative effect on their quality of life [149]. All these aspects must be evaluated before starting KRT, since survival and quality of life are indeed not necessarily better by undergoing dialysis, especially for elderly patients with diabetes and/ or with many diabetes-related complications.

Comprehensive conservative kidney care is understood as a holistic patient-centered care that not only includes interventions to delay CKD progression and minimize complications but also provides detailed communication, shared decision-making, advance care planning, and psychological and family support; however, it does not include dialysis [150]. Older patients, who are socially isolated and have reduced functional capacity and diabetes, are more likely to be offered comprehensive conservative care rather than dialysis [151]. There is almost no evidence about which models of care and which interventions might be most beneficial in the population with diabetes. Many studies have compared outcomes of CKD G5 under conservative versus KRT in elderly patients. Age and DM are identified as decisive factors on prognosis in most of them [149,152]. However, there is a lack of comparative studies focused on the population with diabetes. A case report on a middle-aged woman with DKD that had been followed for 15 years in CKD G5 despite severe disease highlights the need for further studies, not limited exclusively to elderly patients, to verify the efficacy of non-dialysis treatment in patients with diabetes [152].

Knowledge of the main etiologies of CKD and the metabolic alterations and associated symptoms is an important element in providing patients with good palliative care. It should be noted that excessive decreases in blood pressure and glucose levels may be linked with severe complications in CKD G5. Approaches to managing diabetes vary. Individuals previously on insulin therapy are often required to decrease dosages, since insulin is 
metabolized in the renal tubular cells and has its half-life prolonged in CKD G5 [153]. A recent study, among a cohort of US veterans, shows the need for different glycemic strategies based on whether there are plans to transition to dialysis versus pursuing comprehensive conservative care among DKD patients by relating mortality to different glycated hemoglobin targets in each of the groups [154].

In the absence of robust evidence in favor of comprehensive conservative care in patients with diabetes, nephrologists may consider this option in older patients or in those who have higher levels of comorbidity and poorer functional status, independent of the age.

\section{Conclusions}

When patients with DKD progress to severely reduced GFR (CKD G4), they are in a vulnerable situation in which it will be necessary to continue efforts to delay the progression to KF (CKD G5), while controlling CV risk factors and/or vascular complications associated with diabetes. It should also be borne in mind that in the situation of advanced kidney injury, less scientific evidence is available and the use of certain pharmacological tools is restricted. At the same time, it is important to recall that when the progression of kidney disease cannot be delayed, other possibilities to improve the patient's quality of life, such as dialysis, renal transplantation or conservative management, should be explored. Therefore, a shared decision-making process between health care agents, patients and family members should be initiated at this point. In this process, the clinical circumstances and preferences of the patient should be taken into account. In certain cases, it should be considered whether comprehensive conservative care is appropriate. For all this, it is essential to have an adequate multidisciplinary team and sufficient time to devote to the patient and his or her family.

Author Contributions: M.P.-V. has contributed to Delaying the progression of diabetic kidney disease in patients with CKD G4 and Patient decision-making. L.C. has contributed to Delaying the progression of diabetic kidney disease in patients with CKD G4 and Prediction of cardiovascular events and progression. P.d.S. has contributed to indications in in-center HD. N.V. has contributed to indications in P.d.S. M.S. has contributed to Comprehensive conservative care and M.D.D.P. has contributed to indications in home-HD. J.C.R. has contributed to indications in renal transplant. J.M.B. has realized the design of the review and provided an overview on whole articles providing to tables, English text and assembly work. All authors have read and agreed to the published version of the manuscript.

Funding: This research received no external funding.

Institutional Review Board Statement: The ethical review and approval of this study was waived, because it is a bibliographic review and did not involve the participation of patients.

Informed Consent Statement: Patient consent was waived because it is a narrative review and there was no patient involvement.

Data Availability Statement: Not applicable.

Acknowledgments: Juan Gervasio Rebolo Rocafor manuscript professionally editing. To Jose María Mora, for his valuable suggestions to improve this review.

Conflicts of Interest: The authors declare no conflict of interest. 


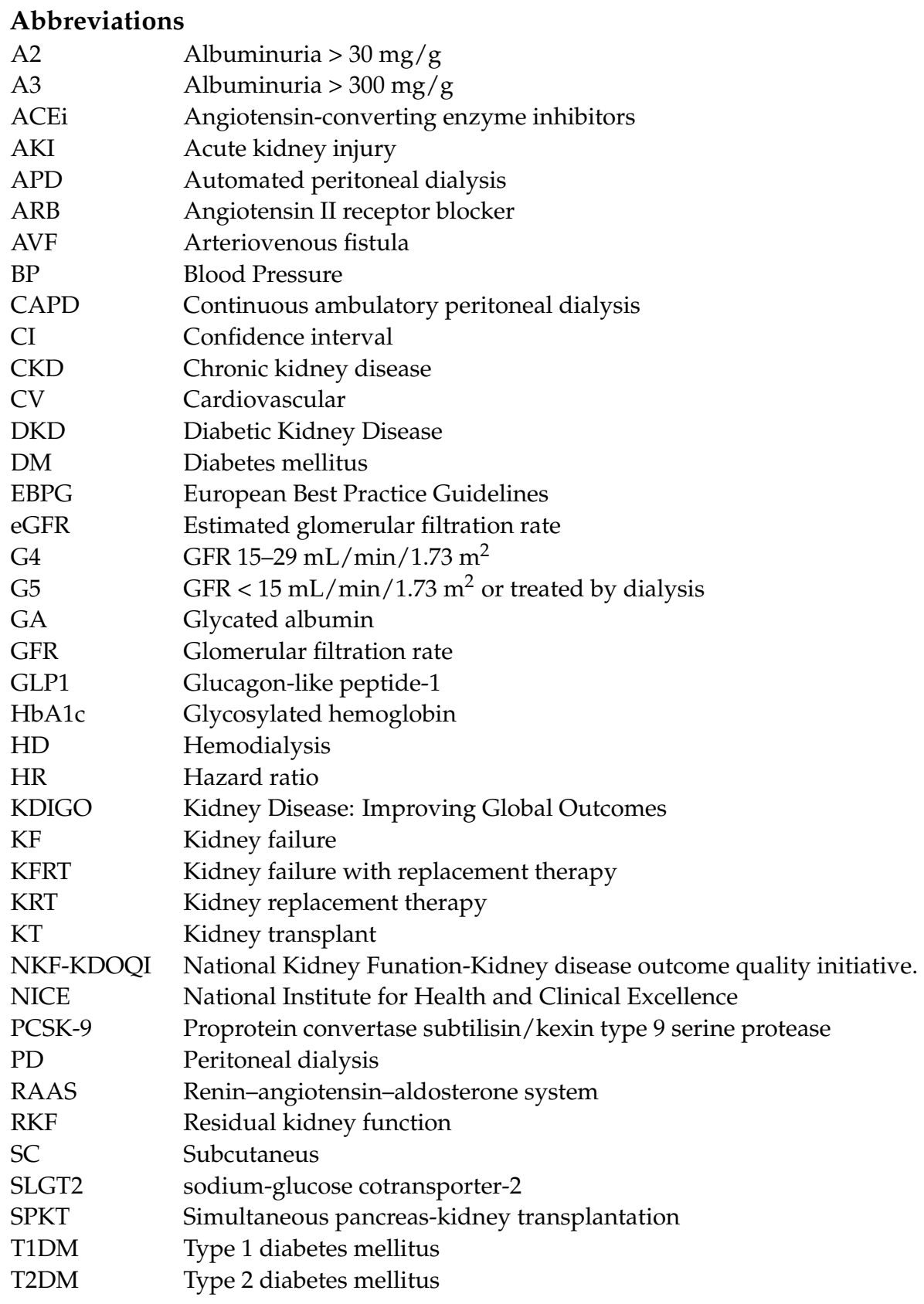

\section{References}

1. Group KDIGO. KDIGO 2012 clinical practice guideline for the evaluation and management of chronic kidney disease Clinical Practice Guidelines. Kidney Int. Suppl. 2013, 3, 1-150.

2. Tonelli, M.; Muntner, P.; Lloyd, A.; Manns, B.J.; Klarenbach, S.; Pannu, N.; James, M.T.; Hemmelgarn, B.R. Risk of coronary events in people with chronic kidney disease compared with those with diabetes: A population-level cohort study. Lancet 2012, 380, 807-814. [CrossRef]

3. Cosentino, F.; Grant, P.J.; Aboyans, V.; Bailey, C.J.; Ceriello, A.; Delgado, V.; Federici, M.; Filippatos, G.; Grobbee, D.E.; Hansen, T.B.; et al. 2019 ESC Guidelines on diabetes, pre-diabetes, and cardiovascular diseases developed in collaboration with the EASD. Eur. Heart J. 2020, 41, 255-323. [CrossRef]

4. Afkarian, M.; Sachs, M.C.; Kestenbaum, B.; Hirsch, I.B.; Tuttle, K.R.; Himmelfarb, J.; Boer, I.H.D. Kidney disease and increased mortality risk in type 2 diabetes. J. Am. Soc. Nephrol. 2013, 24, 302-308. [CrossRef] [PubMed]

5. SEN. Informe de Diálisis y Trasplante 2019; Registro Español de Enfermos Renales; Sociedad Española de Nefrología: Madrid, Spain, 2019.

6. Levey, A.S.; Eckardt, K.-U.; Dorman, N.M.; Christiansen, S.L.; Cheung, M.; Jadoul, M.; Winkelmayer, W.C. Nomenclature for Kidney Function and Disease: Executive Summary and Glossary from a Kidney Disease: Improving Global Outcomes (KDIGO) Consensus Conference. Kidney Dis. 2020, 6, 309-317. [CrossRef] [PubMed] 
7. Chadban, S.J.; Ahn, C.; Axelrod, D.A.; Foster, B.J.; Kasiske, B.L.; Kher, V.; Kumar, D.; Oberbauer, R.; Pascual, J.; Pilmore, H.L.; et al. KDIGO Clinical Practice Guideline on the Evaluation and Management of Candidates for Kidney Transplantation. Transplantation 2020, 104, S11-S103. [CrossRef] [PubMed]

8. $\quad$ Eckardt, K.U.; Bansal, N.; Coresh, J.; Evans, M.; Grams, M.E.; Herzog, C.A.; James, M.T.; Heerspink, H.J.L.; Pollock, C.A.; Stevens, P.E.; et al. Improving the prognosis of patients with severely decreased glomerular filtration rate (CKD G4+): Conclusions from a Kidney Disease: Improving Global Outcomes (KDIGO) Controversies Conference. Kidney Int. 2018, 93, 1281-1292. [CrossRef]

9. Evans, M.; Lopau, K. The transition clinic in chronic kidney disease care. Nephrol. Dial. Transplant. 2020, 35, II4-II10. [CrossRef]

10. Finne, P.; Groop, P.H.; Arffman, M.; Kervinen, M.; Helve, J.; Grönhagen-Riska, C.; Sund, R. Cumulative risk of end-stage renal disease among patients with type 2 diabetes: A nationwide inception cohort study. Diabetes Care 2019, 42, 539-544. [CrossRef]

11. Colombo, M.; McGurnaghan, S.J.; Bell, S.; MacKenzie, F.; Patrick, A.W.; Petrie, J.R.; McKnight, J.A.; MacRury, S.; Traynor, J.; Metcalfe, W.; et al. Predicting renal disease progression in a large contemporary cohort with type 1 diabetes mellitus. Diabetologia 2020, 63, 636-647. [CrossRef] [PubMed]

12. Goderis, G.; Van Pottelbergh, G.; Truyers, C.; Van Casteren, V.; De Clercq, E.; Van Den Broeke, C.; Buntinx, F. Long-term evolution of renal function in patients with type 2 diabetes mellitus: A registry-based retrospective cohort study. BMJ Open 2013, 3, e004029. [CrossRef] [PubMed]

13. Bramlage, P.; Lanzinger, S.; Hess, E.; Fahrner, S.; Heyer, C.H.J.; Friebe, M.; Buschmann, I.; Danne, T.; Holl, R.W.; Seufert, J. Renal function deterioration in adult patients with type-2 diabetes. BMC Nephrol. 2020, 21, 312. [CrossRef]

14. Pavkov, M.E.; Collins, A.J.; Coresh, J.; Nelson, R.G. Kidney Disease in Diabetes. Chapter 22. In Diabetes in America, 3rd ed.; NIH Pub No. 17-1468; Cowie, C.C., Casagrande, S.S., Menke, A., Cissell, M.A., Eberhardt, M.S., Meigs, J.B., Gregg, E.W., Knowler, W.C., Barrett-Connor, E., Becker, D.J., et al., Eds.; National Institutes of Diabetes and Digestive and Kidney Diseases (US): Bethesda, MD, USA, 2018; pp. 22.1-22.84.

15. Kopel, J.; Pena-Hernandez, C.; Nugent, K. Evolving spectrum of diabetic nephropathy. World J. Diabetes 2019, 10, 269-279. [CrossRef]

16. Karalliedde, J.; Viberti, G. Proteinuria in diabetes: Bystander or pathway to cardiorenal disease? J. Am. Soc. Nephrol. 2010, 21, 2020-2027. [CrossRef]

17. Haneda, M.; Utsunomiya, K.; Koya, D.; Babazono, T.; Moriya, T.; Makino, H.; Kimura, K.; Suzuki, Y.; Wada, T.; Ogawa, S.; et al. A new classification of Diabetic Nephropathy 2014: A report from Joint Committee on Diabetic Nephropathy. Clin. Exp. Nephrol. 2015, 19, 242-246. [CrossRef]

18. Thakar, C.V.; Christianson, A.; Himmelfarb, J.; Leonard, A.C. Acute kidney injury episodes and chronic kidney disease risk in diabetes mellitus. Clin. J. Am. Soc. Nephrol. 2011, 6, 2567-2572. [CrossRef] [PubMed]

19. Hill, J.; Nielsen, M.; Fox, M.H. Understanding the social factors that contribute to diabetes: A means to informing health care and social policies for the chronically ill. Perm. J. 2013, 17, 67-72. [CrossRef] [PubMed]

20. Seaquist, E.R.; Goetz, F.C.; Rich, S.; Barbosa, J. Familial Clustering of Diabetic Kidney Disease. N. Engl. J. Med. 1989, 320, 1161-1165. [CrossRef] [PubMed]

21. Giandalia, A.; Giuffrida, A.E.; Gembillo, G.; Cucinotta, D.; Squadrito, G.; Santoro, D.; Russo, G.T. Gender Differences in Diabetic Kidney Disease: Focus on Hormonal, Genetic and Clinical Factors. Int. J. Mol. Sci. 2021, 22, 5808. [CrossRef]

22. Fu, H.; Liu, S.; Bastacky, S.I.; Wang, X.; Tian, X.J.; Zhou, D. Diabetic kidney diseases revisited: A new perspective for a new era. Mol. Metab. 2019, 30, 250-263. [CrossRef]

23. Fava, S.; Hattersley, A.T. The role of genetic susceptibility in diabetic nephropathy: Evidence from family studies. Nephrol. Dial. Transplant. 2002, 17, 1543-1546. [CrossRef]

24. Umanath, K.; Lewis, J.B. Update on Diabetic Nephropathy: Core Curriculum 2018. Am. J. Kidney Dis. 2018, 71, 884-895. [CrossRef]

25. Canani, L.H.; Gerchman, F.; Gross, J.L. Increased familial history of arterial hypertension, coronary heart disease, and renal disease in Brazilian diabetic patients with diabetic nephropathy. Diabetes Care 1998, 21, 1545-1550. [CrossRef] [PubMed]

26. Davis, T.M.E.; Coleman, R.L.; Holman, R.R. Ethnicity and long-term vascular outcomes in Type 2 diabetes: A prospective observational study (UKPDS 83). Diabet. Med. 2014, 31, 200-207. [CrossRef] [PubMed]

27. Boussageon, R.; Bejan-Angoulvant, T.; Saadatian-Elahi, M.; Lafont, S.; Bergeonneau, C.; Kassaï, B.; Erpeldinger, S.; Wright, J.M.; Gueyffier, F.; Cornu, C. Effect of intensive glucose lowering treatment on all cause mortality, cardiovascular death, and microvascular events in type 2 diabetes: Meta-analysis of randomised controlled trials. BMJ 2011, 343. [CrossRef]

28. Coca, S.G.; Ismail-Beigi, F.; Haq, N.; Krumholz, H.M.; Parikh, C.R. Role of intensive glucose control in development of renal end points in type 2 diabetes mellitus: Systematic review and meta-analysis. Arch. Intern. Med. 2012, 172, 761-769. [CrossRef]

29. Ramirez, S.P.B.; McCullough, K.P.; Thumma, J.R.; Nelson, R.G.; Morgenstern, H.; Gillespie, B.W.; Inaba, M.; Jacobson, S.H.; Vanholder, R.; Pisoni, R.L.; et al. Hemoglobin A1c levels and mortality in the diabetic hemodialysis population: Findings from the Dialysis Outcomes and Practice Patterns Study (DOPPS). Diabetes Care 2012, 35, 2527-2532. [CrossRef]

30. Bilo, H.; Coentrão, L.; Couchoud, C.; Covic, A.; De Sutter, J.; Drechsler, C.; Gnudi, L.; Goldsmith, D.; Heaf, J.; Heimburger, O.; et al. Clinical practice guideline on management of patients with diabetes and chronic kidney disease stage $3 \mathrm{~b}$ or higher (EGFR < $45 \mathrm{~mL} / \mathrm{min}$ ). Nephrol. Dial. Transplant. 2015, 30, ii1-ii142. [CrossRef]

31. Hemmingsen, B.; Lund, S.S.; Gluud, C.; Vaag, A.; Almdal, T.; Hemmingsen, C.; Wetterslev, J. Targeting intensive glycaemic control versus targeting conventional glycaemic control for type 2 diabetes mellitus. Cochrane Database Syst. Rev. 2013, 11, CD008143. 
32. de Boer, I.H.; Caramori, M.L.; Chan, J.C.N.; Heerspink, H.J.L.; Hurst, C.; Khunti, K.; Liew, A.; Michos, E.D.; Navaneethan, S.D.; Olowu, W.A.; et al. Executive summary of the 2020 KDIGO Diabetes Management in CKD Guideline: Evidence-based advances in monitoring and treatment. Kidney Int. 2020, 98, 839-848. [CrossRef] [PubMed]

33. Heerspink, H.J.L.; Stefánsson, B.V.; Correa-Rotter, R.; Chertow, G.M.; Greene, T.; Hou, F.-F.; Mann, J.F.E.; McMurray, J.J.V.; Lindberg, M.; Rossing, P.; et al. Dapagliflozin in Patients with Chronic Kidney Disease. N. Engl. J. Med. 2020, 383, 1436-1446. [CrossRef] [PubMed]

34. Perkovic, V.; Jardine, M.J.; Neal, B.; Bompoint, S.; Heerspink, H.J.L.; Charytan, D.M.; Edwards, R.; Agarwal, R.; Bakris, G.; Bull, S.; et al. Canagliflozin and Renal Outcomes in Type 2 Diabetes and Nephropathy. N. Engl. J. Med. 2019, 380, 2295-2306. [CrossRef]

35. Bakris, G.; Oshima, M.; Mahaffey, K.W.; Agarwal, R.; Cannon, C.P.; Capuano, G.; Charytan, D.M.; de Zeeuw, D.; Edwards, R.; Greene, T.; et al. Effects of canagliflozin in patients with baseline eGFR $<30 \mathrm{~mL} / \mathrm{min}$ per $1.73 \mathrm{~m}^{2}$ : Subgroup analysis of the randomized CREDENCE trial. Clin. J. Am. Soc. Nephrol. 2020, 15, 1705-1714. [CrossRef] [PubMed]

36. Margetts, B.M. United Kingdom prospective diabetes study. BMJ 1995, 310, 1005. [CrossRef] [PubMed]

37. Bennett, W.L.; Maruthur, N.M.; Singh, S.; Segal, J.B.; Wilson, L.M.; Chatterjee, R.; Marinopoulos, S.S.; Puhan, M.A.; Ranasinghe, P.; Block, L.; et al. Comparative effectiveness and safety of medications for type 2 diabetes: An update including new drugs and 2-drug combinations. Ann. Intern. Med. 2011, 154, 602-618. [CrossRef] [PubMed]

38. Maruthur, N.M.; Tseng, E.; Hutfless, S.; Wilson, L.M.; Suarez-Cuervo, C.; Berger, Z.; Chu, Y.; Iyoha, E.; Segal, J.B.; Bolen, S. Diabetes medications as monotherapy or metformin-based combination therapy for type 2 diabetes: A systematic review and meta-analysis. Ann. Intern. Med. 2016, 164, 740-751. [CrossRef]

39. Neal, B.; Perkovic, V.; Mahaffey, K.W.; De Zeeuw, D.; Fulcher, G.; Erondu, N.; Shaw, W.; Law, G.; Desai, M.; Matthews, D.R. Canagliflozin and cardiovascular and renal events in type 2 diabetes. N. Engl. J. Med. 2017, 377, 644-657. [CrossRef]

40. Wiviott, S.D.; Raz, I.; Bonaca, M.P.; Mosenzon, O.; Kato, E.T.; Cahn, A.; Silverman, M.G.; Zelniker, T.A.; Kuder, J.F.; Murphy, S.A.; et al. Dapagliflozin and Cardiovascular Outcomes in Type 2 Diabetes. N. Engl. J. Med. 2019, 380, 347-357. [CrossRef]

41. Zinman, B.; Wanner, C.; Lachin, J.M.; Fitchett, D.; Bluhmki, E.; Hantel, S.; Mattheus, M.; Devins, T.; Johansen, O.E.; Woerle, H.J.; et al. Empagliflozin, Cardiovascular Outcomes, and Mortality in Type 2 Diabetes. N. Engl. J. Med. 2015, 373, $2117-2128$. [CrossRef] [PubMed]

42. Marso, S.P.; Bain, S.C.; Consoli, A.; Eliaschewitz, F.G.; Jódar, E.; Leiter, L.A.; Lingvay, I.; Rosenstock, J.; Seufert, J.; Warren, M.L.; et al. Semaglutide and Cardiovascular Outcomes in Patients with Type 2 Diabetes. N. Engl. J. Med. 2016, 375, 1834-1844. [CrossRef] [PubMed]

43. Mann, J.F.E.; Ørsted, D.D.; Brown-Frandsen, K.; Marso, S.P.; Poulter, N.R.; Rasmussen, S.; Tornøe, K.; Zinman, B.; Buse, J.B. Liraglutide and Renal Outcomes in Type 2 Diabetes. N. Engl. J. Med. 2017, 377, 839-848. [CrossRef] [PubMed]

44. Gerstein, H.C.; Colhoun, H.M.; Dagenais, G.R.; Diaz, R.; Lakshmanan, M.; Pais, P.; Probstfield, J.; Riesmeyer, J.S.; Riddle, M.C.; Rydén, L.; et al. Dulaglutide and cardiovascular outcomes in type 2 diabetes (REWIND): A double-blind, randomised placebocontrolled trial. Lancet 2019, 394, 121-130. [CrossRef]

45. Hernandez, A.F.; Green, J.B.; Janmohamed, S.; D’Agostino, R.B.; Granger, C.B.; Jones, N.P.; Leiter, L.A.; Rosenberg, A.E.; Sigmon, K.N.; Somerville, M.C.; et al. Albiglutide and cardiovascular outcomes in patients with type 2 diabetes and cardiovascular disease (Harmony Outcomes): A double-blind, randomised placebo-controlled trial. Lancet 2018, 392, 1519-1529. [CrossRef]

46. Tuttle, K.R.; Lakshmanan, M.C.; Rayner, B.; Busch, R.S.; Zimmermann, A.G.; Woodward, D.B.; Botros, F.T. Dulaglutide versus insulin glargine in patients with type 2 diabetes and moderate-to-severe chronic kidney disease (AWARD-7): A multicentre, open-label, randomised trial. Lancet Diabetes Endocrinol. 2018, 6, 605-617. [CrossRef]

47. Das, S.R.; Everett, B.M.; Birtcher, K.K.; Brown, J.M.; Cefalu, W.T.; Januzzi, J.L.; Kalyani, R.R.; Kosiborod, M.; Magwire, M.L.; Morris, P.B.; et al. 2018 ACC Expert Consensus Decision Pathway on Novel Therapies for Cardiovascular Risk Reduction in Patients With Type 2 Diabetes and Atherosclerotic Cardiovascular Disease: A Report of the American College of Cardiology Task Force on Expert Consensus Deci. J. Am. Coll. Cardiol. 2018, 72, 3200-3223. [CrossRef]

48. Davies, M.J.; D’Alessio, D.A.; Fradkin, J.; Kernan, W.N.; Mathieu, C.; Mingrone, G.; Rossing, P.; Tsapas, A.; Wexler, D.J.; Buse, J.B. Management of hyperglycemia in type 2 diabetes, 2018. A consensus report by the American Diabetes Association (ADA) and the european association for the study of diabetes (EASD). Diabetes Care 2018, 41, 2669-2701. [CrossRef]

49. Górriz, J.L.; Soler, M.J.; Navarro-González, J.F.; García-Carro, C.; Puchades, M.J.; D’Marco, L.; Martínez Castelao, A.; Fernández-Fernández, B.; Ortiz, A.; Górriz-Zambrano, C.; et al. GLP-1 Receptor Agonists and Diabetic Kidney Disease: A Call of Attention to Nephrologists. J. Clin. Med. 2020, 9, 947. [CrossRef] [PubMed]

50. Whelton, P.K.; Carey, R.M.; Aronow, W.S.; Casey, D.E.; Collins, K.J.; Himmelfarb, C.D.; DePalma, S.M.; Gidding, S.; Jamerson, K.A.; Jones, D.W.; et al. 2017 ACC/AHA/AAPA/ABC/ACPM/AGS/APhA/ASH/ASPC/NMA/PCNA guideline for the prevention, detection, evaluation, and management of high blood pressure in adults: Executive summary: A report of the American college of cardiology / American Heart Association task. Hypertension 2018, 71, 1269-1324. [CrossRef]

51. Nagata, D.; Hishida, E.; Masuda, T. Practical strategy for treating chronic kidney disease (CKD)-associated with hypertension. Int. J. Nephrol. Renovasc. Dis. 2020, 13, 171-178. [CrossRef]

52. Palmer, S.C.; Mavridis, D.; Navarese, E.; Craig, J.C.; Tonelli, M.; Salanti, G.; Wiebe, N.; Ruospo, M.; Wheeler, D.C.; Strippoli, G.F.M. Comparative efficacy and safety of blood pressure-lowering agents in adults with diabetes and kidney disease: A network meta-analysis. Lancet 2015, 385, 2047-2056. [CrossRef] 
53. Filippatos, G.; Anker, S.D.; Agarwal, R.; Pitt, B.; Ruilope, L.M.; Rossing, P.; Kolkhof, P.; Schloemer, P.; Tornus, I.; Joseph, A.; et al. Finerenone and Cardiovascular Outcomes in Patients with Chronic Kidney Disease and Type 2 Diabetes. Circulation 2021, 143, 540-552. [CrossRef] [PubMed]

54. Bakris, G.L.; Agarwal, R.; Anker, S.D.; Pitt, B.; Ruilope, L.M.; Rossing, P.; Kolkhof, P.; Nowack, C.; Schloemer, P.; Joseph, A.; et al. Effect of Finerenone on Chronic Kidney Disease Outcomes in Type 2 Diabetes. N. Engl. J. Med. 2020, 383, 2219-2229. [CrossRef] [PubMed]

55. Iglay, K.; Hannachi, H.; Howie, P.J.; Xu, J.; Li, X.; Engel, S.S.; Moore, L.M.; Rajpathak, S. Prevalence and co-prevalence of comorbidities among patients with type 2 diabetes mellitus. Curr. Med. Res. Opin. 2016, 32, 1243-1252. [CrossRef] [PubMed]

56. Baigent, C.; Landray, M.J.; Reith, C.; Emberson, J.; Wheeler, D.C.; Tomson, C.; Wanner, C.; Krane, V.; Cass, A.; Craig, J.; et al. The effects of lowering LDL cholesterol with simvastatin plus ezetimibe in patients with chronic kidney disease (Study of Heart and Renal Protection): A randomised placebo-controlled trial. Lancet 2011, 377, 2181-2192. [CrossRef]

57. Haynes, R.; Lewis, D.; Emberson, J.; Reith, C.; Agodoa, L.; Cass, A.; Craig, J.C.; De Zeeuw, D.; Feldt-Rasmussen, B.; Fellstr'm, B.; et al. Effects of lowering LDL cholesterol on progression of kidney disease. J. Am. Soc. Nephrol. 2014, 25, 1825-1833. [CrossRef] [PubMed]

58. Mark, P.B.; Winocour, P.; Day, C. Management of lipids in adults with diabetes mellitus and nephropathy and/or chronic kidney disease: Summary of joint guidance from the Association of British Clinical Diabetologists (ABCD) and the Renal Association (RA). Br. J. Diabetes Vasc. Dis. 2017, 17, 64-72. [CrossRef]

59. Pontremoli, R.; Bellizzi, V.; Bianchi, S.; Bigazzi, R.; Cernaro, V.; Del Vecchio, L.; De Nicola, L.; Leoncini, G.; Mallamaci, F.; Zoccali, C.; et al. Management of dyslipidaemia in patients with chronic kidney disease: A position paper endorsed by the Italian Society of Nephrology. J. Nephrol. 2020, 33, 417-430. [CrossRef]

60. Cupisti, A.; Brunori, G.; Di Iorio, B.R.; D’Alessandro, C.; Pasticci, F.; Cosola, C.; Bellizzi, V.; Bolasco, P.; Capitanini, A.; Fantuzzi, A.L.; et al. Nutritional treatment of advanced CKD: Twenty consensus statements. J. Nephrol. 2018, 31, 457-473. [CrossRef]

61. Goldstein-Fuchs, J.; Kalantar-Zadeh, K. Nutrition intervention for advanced stages of diabetic kidney disease. Diabetes Spectr. 2015, 28, 181-186. [CrossRef]

62. de Borst, M.H.; Navis, G. Role of sodium status in the clinical management of diabetic nephropathy: Interaction with RAASblockade efficacy. Diabetes Manag. 2015, 5, 229-243. [CrossRef]

63. DeFronzo, R.A.; Reeves, W.B.; Awad, A.S. Pathophysiology of diabetic kidney disease: Impact of SGLT2 inhibitors. Nat. Rev. Nephrol. 2021, 17, 319-334. [CrossRef]

64. Navaneethan, S.D.; Shao, J.; Buysse, J.; Bushinsky, D.A. Effects of treatment of metabolic acidosis in CKD: A systematic review and meta-analysis. Clin. J. Am. Soc. Nephrol. 2019, 14, 1011-1020. [CrossRef] [PubMed]

65. Weldegiorgis, M.; de Zeeuw, D.; Li, L.; Parving, H.H.; Hou, F.F.; Remuzzi, G.; Greene, T.; Heerspink, H.J.L. Longitudinal Estimated GFR Trajectories in Patients With and Without Type 2 Diabetes and Nephropathy. Am. J. Kidney Dis. 2018, 71, 91-101. [CrossRef]

66. Doshi, S.M.; Friedman, A.N. Diagnosis and management of type 2 diabetic kidney disease. Clin. J. Am. Soc. Nephrol. 2017, 12, 1366-1373. [CrossRef] [PubMed]

67. Yamanouchi, M.; Hoshino, J.; Ubara, Y.; Takaichi, K.; Kinowaki, K.; Fujii, T.; Ohashi, K.; Mise, K.; Toyama, T.; Hara, A.; et al. Value of adding the renal pathological score to the kidney failure risk equation in advanced diabetic nephropathy. PLoS ONE 2018, 13, e0190930. [CrossRef]

68. Palanca, A.; Castelblanco, E.; Betriu, À.; Perpiñán, H.; Soldevila, B.; Valdivielso, J.M.; Bermúdez-Lopez, M.; Puig-Jové, C.; Puig-Domingo, M.; Groop, P.H.; et al. Subclinical atherosclerosis burden predicts cardiovascular events in individuals with diabetes and chronic kidney disease. Cardiovasc. Diabetol. 2019, 18, 93. [CrossRef] [PubMed]

69. Katakami, N.; Mita, T.; Gosho, M.; Takahara, M.; Irie, Y.; Yasuda, T.; Matsuoka, T.A.; Osonoi, T.; Watada, H.; Shimomura, I. Clinical utility of carotid ultrasonography in the prediction of cardiovascular events in patients with diabetes: A combined analysis of data obtained in five longitudinal studies. J. Atheroscler. Thromb. 2018, 25, 1053-1066. [CrossRef] [PubMed]

70. Sharief, S.; Hsu, C. yuan The Transition From the Pre-ESRD to ESRD Phase of CKD: Much Remains to Be Learned. Am. J. Kidney Dis. 2017, 69, 8-10. [CrossRef] [PubMed]

71. Prieto-Velasco, M.; Bagnis, C.I.; Dean, J.; Goovaerts, T.; Melander, S.; Mooney, A.; Nilsson, E.L.; Rutherford, P.; Trujillo, C.; Zambon, R.; et al. Predialysis education in practice: A questionnaire survey of centres with established programmes. BMC Res. Notes 2014, 7, 730. [CrossRef] [PubMed]

72. Zimbudzi, E.; Lo, C.; Misso, M.L.; Ranasinha, S.; Kerr, P.G.; Teede, H.J.; Zoungas, S. Effectiveness of self-management support interventions for people with comorbid diabetes and chronic kidney disease: A systematic review and meta-analysis. Syst. Rev. 2018, 7. [CrossRef]

73. Prieto-Velasco, M.; Quiros, P.; Remon, C.; Escobedo, J.M.; Galán, A.; Giménez, M.; Henningsmeyer, B.; Aguilera, A.I.; Novoa, E.; Rodríguez, T.O.A.; et al. The concordance between patients' renal replacement therapy choice and definitive modality: Is it a utopia? PLoS ONE 2015, 10. [CrossRef]

74. Isnard Bagnis, C.; Crepaldi, C.; Dean, J.; Goovaerts, T.; Melander, S.; Nilsson, E.L.; Prieto-Velasco, M.; Trujillo, C.; Zambon, R.; Mooney, A. Quality standards for predialysis education: Results from a consensus conference. Nephrol. Dial. Transplant. 2015, 30, 1058-1066. [CrossRef] 
75. Navaneethan, S.D.; Zoungas, S.; Caramori, M.L.; Chan, J.C.N.; Heerspink, H.J.L.; Hurst, C.; Liew, A.; Michos, E.D.; Olowu, W.A.; Sadusky, T.; et al. Diabetes Management in Chronic Kidney Disease: Synopsis of the 2020 KDIGO Clinical Practice Guideline. Ann. Intern. Med. 2020. [CrossRef] [PubMed]

76. Goovaerts, T.; Bagnis Isnard, C.; Crepaldi, C.; Dean, J.; Melander, S.; Mooney, A.; Prieto-Velasco, M.; Trujillo, C.; Zambon, R.; Nilsson, E.L. Continuing education: Preparing patients to choose a renal replacement therapy. J. Ren. Care 2015, $41,62-75$. [CrossRef] [PubMed]

77. Prieto-Velasco, M.; del Pino y Pino, M.D.; Buades Fuster, J.M.; Craver Hospital, L.; Pons Prades, R.; Ruiz San Millán, J.C.; Salgueira Lazo, M.; de Sequera Ortiz, P.; Vega Díaz, N. Unidades de Enfermedad Renal Crónica Avanzada en España: Una encuesta nacional sobre los estándares de estructura, recursos, resultados y seguridad del paciente. Nefrología 2020, 40, 608-622. [CrossRef] [PubMed]

78. Wiseman, A.C. The role of kidney-pancreas transplantation in diabetic kidney disease. Curr. Diab. Rep. 2010, 10, 385-391. [CrossRef]

79. Fourtounas, C. Transplant options for patients with type 2 diabetes and chronic kidney disease. World J. Transplant. 2014, 4, 102. [CrossRef]

80. Davison, S.N. Facilitating advance care planning for patients with end-stage renal disease: The patient perspective. Clin. J. Am. Soc. Nephrol. 2006, 1, 1023-1028. [CrossRef]

81. Wolfe, R.A.; Ashby, V.B.; Milford, E.L.; Ojo, A.O.; Ettenger, R.E.; Agodoa, L.Y.C.; Held, P.J.; Port, F.K. Comparison of Mortality in All Patients on Dialysis, Patients on Dialysis Awaiting Transplantation, and Recipients of a First Cadaveric Transplant. N. Engl. J. Med. 1999, 341, 1725-1730. [CrossRef]

82. Bittar, J.; Arenas, P.; Chiurchiu, C.; de la Fuente, J.; de Arteaga, J.; Douthat, W.; Massari, P.U. Renal transplantation in high cardiovascular risk patients. Transplant. Rev. 2009, 23, 224-234. [CrossRef]

83. Muntner, P.; He, J.; Hamm, L.; Loria, C.; Whelton, P.K. Renal insufficiency and subsequent death resulting from cardiovascular disease in the United States. J. Am. Soc. Nephrol. 2002, 13, 745-753. [CrossRef]

84. Dinavahi, R.; Akalin, E. Preemptive Kidney Transplantation in Patients with Diabetes Mellitus. Endocrinol. Metab. Clin. N. Am. 2007, 36, 1039-1049. [CrossRef] [PubMed]

85. Pavlakis, M. The timing of dialysis and kidney transplantation in type 1 diabetes. Diabetes Obes. Metab. 2012, 14, 689-693. [CrossRef] [PubMed]

86. Pavlakis, M.; Kher, A. Pre-emptive Kidney Transplantation to Improve Survival in Patients With Type 1 Diabetes and Imminent Risk of ESRD. Semin. Nephrol. 2012, 32, 505-511. [CrossRef]

87. Kasiske, B.L.; Snyder, J.J.; Matas, A.J.; Ellison, M.D.; Gill, J.S.; Kausz, A.T. Preemptive kidney transplantation: The advantage and the advantaged. J. Am. Soc. Nephrol. 2002, 13, 1358-1364. [CrossRef]

88. Becker, B.N.; Rush, S.H.; Dykstra, D.M.; Becker, Y.T.; Port, F.K. Preemptive transplantation for patients with diabetes-related kidney disease. Arch. Intern. Med. 2006, 166, 44-48. [CrossRef]

89. Meier-Kriesche, H.U.; Schold, J.D. The impact of pretransplant dialysis on outcomes in renal transplantation. Semin. Dial. 2005, 18, 499-504. [CrossRef] [PubMed]

90. Luan, F.L.; Samaniego, M. Transplantation in diabetic kidney failure patients: Modalities, outcomes, and clinical Management. Semin. Dial. 2010, 23, 198-205. [CrossRef] [PubMed]

91. Cosio, F.G.; Hickson, L.J.; Griffin, M.D.; Stegall, M.D.; Kudva, Y. Patient survival and cardiovascular risk after kidney transplantation: The challenge of diabetes. Am. J. Transplant. 2008, 8, 593-599. [CrossRef]

92. Golper, T.A.; Churchill, D.; Blake, P.; Burkart, J.; Chatoth, D.K.; Firanek, C.; Geary, D.; Gotch, F.; Kliger, A.S.; Korbet, S.M.; et al NKF-K/DOQI clinical practice guidelines for peritoneal dialysis adequacy: Update 2000. Am. J. Kidney Dis. 2001, 37, S65-S136. [CrossRef]

93. Covic, A.; Bammens, B.; Lobbedez, T.; Segall, L.; Heimbürger, O.; Van Biesen, W.; Fouque, D.; Vanholder, R. Educating end-stage renal disease patients on dialysis modality selection: Clinical advice from the European Renal Best Practice (ERBP) Advisory Board. Nephrol. Dial. Transplant. 2010, 25, 1757-1759. [CrossRef]

94. Gilbert, J.; Lovibond, K.; Mooney, A.; Dudley, J. Renal replacement therapy: Summary of NICE guidance. BMJ 2018, 363, k4303. [CrossRef]

95. Eroglu, E.; Heimbürger, O.; Lindholm, B. Peritoneal dialysis patient selection from a comorbidity perspective. Semin. Dial. 2020. [CrossRef]

96. Coelho, S.; Rodrigues, A. Hemoglobin A1c in Patients on Peritoneal Dialysis: How Should We Interpret It? Ther. Apher. Dial. 2014, 18, 375-382. [CrossRef]

97. Duong, U.; Mehrotra, R.; Molnar, M.Z.; Noori, N.; Kovesdy, C.P.; Nissenson, A.R.; Kalantar-Zadeh, K. Glycemic control and survival in peritoneal dialysis patients with diabetes mellitus. Clin. J. Am. Soc. Nephrol. 2011, 6, 1041-1048. [CrossRef]

98. Sekercioglu, N.; Dimitriadis, C.; Pipili, C.; Elias, R.M.; Kim, J.; Oreopoulos, D.G.; Bargman, J.M. Glycemic control and survival in peritoneal dialysis patients with diabetes mellitus. Int. Urol. Nephrol. 2012, 44, 1861-1869. [CrossRef]

99. Yoo, D.E.; Park, J.T.; Oh, H.J.; Kim, S.J.; Lee, M.J.; Shin, D.H.; Han, S.H.; Yoo, T.H.; Choi, K.H.; Kang, S.W. Good glycemic control is associated with better survival in diabetic patients on peritoneal dialysis: A prospective observational study. PLoS ONE 2012, 7. [CrossRef] [PubMed]

100. Abe, M.; Hamano, T.; Hoshino, J.; Wada, A.; Nakai, S.; Masakane, I. Glycemic control and survival in peritoneal dialysis patients with diabetes: A 2-year nationwide cohort study. Sci. Rep. 2019, 9. [CrossRef] [PubMed]

101. Almalki, M.H.; Altuwaijri, M.A.; Almehthel, M.S.; Sirrs, S.M.; Suneet Singh, R. Subcutaneous versus intraperitoneal insulin for patients with diabetes mellitus on continuous ambulatory peritoneal dialysis: Meta-analysis of non-randomized clinical trials. Clin. Investig. Med. 2012, 35. [CrossRef] 
102. Marrón, B.; Remón, C.; Pérez-Fontán, M.; Quirós, P.; Ortíz, A. Benefits of preserving residual renal function in peritoneal dialysis. Kidney Int. 2008, 73, S42-S51. [CrossRef] [PubMed]

103. Sung, S.A.; Hwang, Y.H.; Kim, S.; Kim, S.G.; Oh, J.; Chung, W.; Lee, S.Y.; Ahn, C.; Oh, K.H. Loss of residual renal function was not associated with glycemic control in patients on peritoneal dialysis. Perit. Dial. Int. 2011, 31, 154-159. [CrossRef]

104. Vega-Diaz, N.; Gonzalez-Cabrera, F.; Marrero-Robayna, S.; Santana-Estupiñan, R.; Gallego-Samper, R.; Henriquez-Palop, F.; Perez-Borges, P.; Rodriguez-Perez, J.C. Renal Replacement Therapy: Purifying Efficiency of Automated Peritoneal Dialysis in Diabetic versus Non-Diabetic Patients. J. Clin. Med. 2015, 4, 1518-1535. [CrossRef]

105. Passadakis, P.S.; Oreopoulos, D.G. Diabetic patients on peritoneal dialysis. Semin. Dial. 2010, 23, 191-197. [CrossRef] [PubMed]

106. Davies, S.J. Peritoneal dialysis-current status and future challenges. Nat. Rev. Nephrol. 2013, 9, 399-408. [CrossRef]

107. Cotovio, P.; Rocha, A.; Carvalho, M.J.; Teixeira, L.; Mendonça, D.; Cabrita, A.; Rodrigues, A. Better outcomes of peritoneal dialysis in diabetic patients in spite of risk of loss of autonomy for home dialysis. Perit. Dial. Int. 2014, 34, 775-780. [CrossRef] [PubMed]

108. Mehrotra, R.; Devuyst, O.; Davies, S.J.; Johnson, D.W. The current state of peritoneal dialysis. J. Am. Soc. Nephrol. 2016, 27, 3238-3252. [CrossRef]

109. Segall, L.; Nistor, I.; Van Biesen, W.; Brown, E.A.; Heaf, J.G.; Lindley, E.; Farrington, K.; Covic, A. Dialysis modality choice in elderly patients with end-stage renal disease: A narrative review of the available evidence. Nephrol. Dial. Transplant. 2017, 32, 41-49. [CrossRef]

110. Guilloteau, S.; Lobbedez, T.; Guillouët, S.; Verger, C.; Ficheux, M.; Lanot, A.; Béchade, C. Impact of Assisted Peritoneal Dialysis Modality on Outcomes: A Cohort Study of the French Language Peritoneal Dialysis Registry. Am. J. Nephrol. 2018, 48, 425-433. [CrossRef]

111. Briggs, V.; Davies, S.; Wilkie, M. International Variations in Peritoneal Dialysis Utilization and Implications for Practice. Am. J. Kidney Dis. 2019, 74, 101-110. [CrossRef] [PubMed]

112. Kennedy, C.; Bargman, J. Peritoneal dialysis in the obese patient. Clin. J. Am. Soc. Nephrol. 2020, 15, 276-278. [CrossRef]

113. Finkelstein, F.O. Barriers to optimal peritoneal dialysis. Semin. Dial. 2020, 33, 464-467. [CrossRef]

114. Beckman, J.A.; Creager, M.A.; Libby, P. Diabetes and atherosclerosis epidemiology, pathophysiology, and management. J. Am. Med. Assoc. 2002, 287, 2570-2581. [CrossRef] [PubMed]

115. Foley, R.N.; Culleton, B.F.; Parfrey, P.S.; Harriett, J.D.; Kent, G.M.; Murray, D.C.; Barre, P.E. Cardiac disease in diabetic end-stage renal disease. Diabetologia 1997, 40,1307-1312. [CrossRef]

116. Ishida, I.; Hirakata, H.; Sugimori, H.; Omae, T.; Hirakata, E.; Ibayashi, S.; Kubo, M.A.; Fujishima, M. Hemodialysis causes severe orthostatic reduction in cerebral blood flow velocity in diabetic patients. Am. J. Kidney Dis. 1999, 34, 1096-1104. [CrossRef]

117. Ghavamian, M.; Gutch, C.F.; Kopp, K.F.; Kolff, W.J. The Sad Truth About Hemodialysis in Diabetic Nephropathy. JAMA J. Am. Med. Assoc. 1972, 222, 1386-1389. [CrossRef]

118. Mori, K.; Nishide, K.; Okuno, S.; Shoji, T.; Emoto, M.; Tsuda, A.; Nakatani, S.; Imanishi, Y.; Ishimura, E.; Yamakawa, T.; et al. Impact of diabetes on sarcopenia and mortality in patients undergoing hemodialysis. BMC Nephrol. 2019, 20, 105. [CrossRef]

119. Ma, L.; Zhao, S. Risk factors for mortality in patients undergoing hemodialysis: A systematic review and meta-analysis. Int. J. Cardiol. 2017, 238, 151-158. [CrossRef] [PubMed]

120. Ricks, J.; Molnar, M.Z.; Kovesdy, C.P.; Shah, A.; Nissenson, A.R.; Williams, M.; Kalantar-Zadeh, K. Glycemic control and cardiovascular mortality in hemodialysis patients with diabetes: A 6-year cohort study. Diabetes 2012, 61, 708-715. [CrossRef]

121. Jeong, S.; Kwon, H.; Chang, J.W.; Kim, M.J.; Ganbold, K.; Han, Y.; Kwon, T.W.; Cho, Y.P. Comparison of outcomes between type 2 diabetic and non-diabetic incident hemodialysis patients with functioning arteriovenous fistulas. Medicine 2019, 98. [CrossRef]

122. Yan, Y.; Ye, D.; Yang, L.; Ye, W.; Zhan, D.; Zhang, L.; Xiao, J.; Zeng, Y.; Chen, Q. A meta-analysis of the association between diabetic patients and AVF failure in dialysis. Ren. Fail. 2018, 40, 379-383. [CrossRef]

123. Robinson, T.W.; Freedman, B.I. Glycated albumin and blood sugar control in advanced chronic kidney disease. Nephrol. Dial. Transplant. 2018, 33, 1087-1090. [CrossRef] [PubMed]

124. Takahashi, S.; Uchino, H.; Shimizu, T.; Kanazawa, A.; Tamura, Y.; Sakai, K.; Watada, H.; Hirose, T.; Kawamori, R.; Tanaka, Y. Comparison of Glycated Albumin (GA) and Glycated Hemoglobin (HbA1c) in type 2 diabetic patients: Usefulness of GA for evaluation of short-term changes in glycemic control. Endocr. J. 2007, 54, 139-144. [CrossRef] [PubMed]

125. Nakao, T.; Inaba, M.; Abe, M.; Kaizu, K.; Shima, K.; Babazono, T.; Tomo, T.; Hirakata, H.; Akizawa, T. Best Practice for Diabetic Patients on Hemodialysis 2012. Ther. Apher. Dial. 2015, 19, 40-66. [CrossRef] [PubMed]

126. Abe, M.; Kalantar-Zadeh, K. Haemodialysis-induced hypoglycaemia and glycaemic disarrays. Nat. Rev. Nephrol. 2015, 11, 302-313. [CrossRef]

127. Besarab, A.; Allon, M.; Robbin, M.L. Resolved: Fistulas are preferred to grafts as initial vascular access for dialysis. J. Am. Soc. Nephrol. 2008, 19, 1629-1633. [CrossRef]

128. Kordzadeh, A.; Chung, J.; Panayiotopoulos, Y.P. Cephalic vein and radial artery diameter in formation of radiocephalic arteriovenous fistula: A systematic review. J. Vasc. Access 2015, 16, 506-511. [CrossRef]

129. Creager, M.A.; Lüscher, T.F.; Cosentino, F.; Beckman, J.A. Diabetes and vascular disease. Pathophysiology, clinical consequences, and medical therapy: Part I. Circulation 2003, 108, 1527-1532. [CrossRef]

130. Gołębiowski, T.; Weyde, W.; Kusztal, M.; Porazko, T.; Augustyniak-Bartosik, H.; Madziarska, K.; Krajewska, M.; Koniński, P.; Sydor, A.; Letachowicz, K.; et al. Vascular access in diabetic patients. Are these patients "difficult"? Postepy Hig. Med. Dosw. 2015, 69, 913-917. [CrossRef]

131. Konner, K. Primary vascular access in diabetic patients: An audit. Nephrol. Dial. Transplant. 2000, 15, 1317-1325. [CrossRef] 
132. Konner, K. Increasing the proportion of diabetics with AV fistulas. Semin. Dial. 2001, 14, 1-4. [CrossRef]

133. Huber, T.S.; Larive, B.; Imrey, P.B.; Radeva, M.K.; Kaufman, J.M.; Kraiss, L.W.; Farber, A.M.; Berceli, S.A. Access-related hand ischemia and the Hemodialysis Fistula Maturation Study. J. Vasc. Surg. 2016, 64, 1050-1058.e1. [CrossRef] [PubMed]

134. Jennings, W.C.; Mallios, A.; Mushtaq, N. Proximal radial artery arteriovenous fistula for hemodialysis vascular access. J. Vasc. Surg. 2018, 67, 244-253. [CrossRef] [PubMed]

135. Lomonte, C.; Basile, C.; Mitra, S.; Combe, C.; Covic, A.; Davenport, A.; Kirmizis, D.; Schneditz, D.; Van Der Sande, F. Should a fistula first policy be revisited in elderly haemodialysis patients? Nephrol. Dial. Transplant. 2019, 34, 1636-1643. [CrossRef]

136. Lin, S.L.; Huang, C.H.; Chen, H.S.; Hsu, W.A.; Yen, C.J.; Yen, T.S. Effects of age and diabetes on blood flow rate and primary outcome of newly created hemodialysis arteriovenous fistulas. Am. J. Nephrol. 1998, 18, 96-100. [CrossRef] [PubMed]

137. Susantitaphong, P.; Koulouridis, I.; Balk, E.M.; Madias, N.E.; Jaber, B.L. Effect of frequent or extended hemodialysis on cardiovascular parameters: A meta-analysis. Am. J. Kidney Dis. 2012, 59, 689-699. [CrossRef]

138. Assimon, M.M.; Flythe, J.E. Definitions of intradialytic hypotension. Semin. Dial. 2017, 30, 464-472. [CrossRef]

139. Cornelis, T.; Tennankore, K.K.; Goffin, E.; Rauta, V.; Honkanen, E.; Özyilmaz, A.; Thanaraj, V.; Jayanti, A.; Mitra, S.; Van Der Sande, F.M.; et al. An international feasibility study of home haemodialysis in older patients. Nephrol. Dial. Transplant. 2014, 29, 2327-2333. [CrossRef] [PubMed]

140. Kraus, M.A.; Fluck, R.J.; Weinhandl, E.D.; Kansal, S.; Copland, M.; Komenda, P.; Finkelstein, F.O. Intensive Hemodialysis and Health-Related Quality of Life. Am. J. Kidney Dis. 2016, 68, S33-S42. [CrossRef] [PubMed]

141. Daugirdas, J.T.; Depner, T.A.; Inrig, J.; Mehrotra, R.; Rocco, M.V.; Suri, R.S.; Weiner, D.E.; Greer, N.; Ishani, A.; MacDonald, R.; et al. KDOQI Clinical Practice Guideline for Hemodialysis Adequacy: 2015 Update. Am. J. Kidney Dis. 2015, 66, 884-930. [CrossRef]

142. Barril, G.; Sánchez Tomero, J.A. La hemodiálisis domiciliaria alternativa posible y necesaria. Nefrologia 2007, $27,3-5$.

143. National Institute of Clinical Excellence. Full Guidance on Home Compared with Hospital Haemodialysis for Patients with End-Stage Renal Failure October 2002. Available online: https:/ / www.google.es/search?sxsrf=ALeKk01POf-eeNyMqsIvxywIv2 ari1PYEg\%253A1614275789212\&ei=zeQ3YOq0DMaflwSU2rmQBA\&q=Full+guidance+on+home+compared+with+hospital+ haemodialysis+for+patients+with+end-stage+renal+failure+October+\%25282002\%2529.+\%2528www.nice.org.+uk\%25 (accessed on 25 February 2021).

144. Diabetes Kidney Group, K.D.I.G.O. (KDIGO) KDIGO 2020 Clinical Practice Guideline for Diabetes Management in Chronic Kidney Disease. Kidney Int. 2020, 98, S1-S115. [CrossRef]

145. Murtagh, F.E.M.; Addington-Hall, J.M.; Donohoe, P.; Higginson, I.J. Symptom management in patients with established renal failure managed without dialysis. EDTNA-ERCA J. 2006, 32, 93-98. [CrossRef] [PubMed]

146. Brunori, G.; Viola, B.F.; Maiorca, P.; Cancarini, G. How to manage elderly patients with chronic renal failure: Conservative management versus dialysis. Blood Purif. 2008, 26, 36-40. [CrossRef]

147. Zaoui, P.; Hannedouche, T.; Combe, C. La protection cardiovasculaire du patient diabétique avec maladie rénale chronique et cas particulier de l'insuffisance rénale chronique terminale du sujet âgé. Nephrol. Ther. 2017, 13, S1-S6. [CrossRef]

148. Baiardi, F.; Esposti, E.D.; Cocchi, R.; Fabbri, A.; Sturani, A.; Valpiani, G.; Fusaroli, M. Effects of clinical and individual variables on quality of life in chronic renal failure patients. J. Nephrol. 2002, 15, 61-67.

149. Murtagh, F.E.M.; Burns, A.; Moranne, O.; Morton, R.L.; Naicker, S. Supportive care: Comprehensive conservative care in end-stage kidney disease. Clin. J. Am. Soc. Nephrol. 2016, 11, 1909-1914. [CrossRef]

150. Joly, D.; Anglicheau, D.; Alberti, C.; Nguyen, A.T.; Touam, M.; Grünfeld, J.P.; Jungers, P. Octogenarians reaching end-stage renal disease: Cohort study of decision-making and clinical outcomes. J. Am. Soc. Nephrol. 2003, 14, 1012-1021. [CrossRef]

151. Williams, A.W.; Dwyer, A.C.; Eddy, A.A.; Fink, J.C.; Jaber, B.L.; Linas, S.L.; Michael, B.; O’Hare, A.M.; Schaefer, H.M.; Shaffer, R.N.; et al. Critical and honest conversations: The evidence behind the "choosing Wisely" campaign recommendations by the American society of nephrology. Clin. J. Am. Soc. Nephrol. 2012, 7, 1664-1672. [CrossRef]

152. Pacilio, M.; Minutolo, R.; Garofalo, C.; Liberti, M.E.; Conte, G.; De Nicola, L. Stage 5-CKD under nephrology care: To dialyze or not to dialyze, that is the question. J. Nephrol. 2016, 29, 153-161. [CrossRef]

153. Castro, M.C.M. Conservative management for patients with chronic kidney disease refusing dialysis. J. Bras. Nefrol. 2019, 41, 95-102. [CrossRef]

154. Rhee, C.M.; Kovesdy, C.P.; Ravel, V.A.; Streja, E.; Sim, J.J.; You, A.S.; Gatwood, J.; Amin, A.N.; Molnar, M.Z.; Nguyen, D.V.; et al. Glycemic Status and Mortality in Chronic Kidney Disease According to Transition Versus Nontransition to Dialysis. J. Ren. Nutr. 2019, 29, 82-90. [CrossRef] [PubMed] 